\title{
The Principle of Hadley v. Baxendale
}

\author{
Melvin Aron Eisenberg†
}

From the classic contract-law case of Hadley v. Baxendale came the principle that consequential damages can be recovered only if, at the time the contract was made, the breaching party had reason to foresee that consequential damages would be the probable result of breach. As traditionally formulated, the principle's standard of foreseeability has been strict and inflexible. This formulation diverges from both the general principle of expectation damages in contract law and the principle of proximate cause outside the law of contract. Professor Eisenberg argues that neither least-cost theory, the theory of efficient breach, nor information-forcing incentives justify the principle of Hadley v. Baxendale. He recommends that the principle be replaced by a regime of proximate cause, contractual allocation of loss, and fair disclosure. The new regime would adjust the standard of foreseeability according to the nature of the interest and the wrong, and would apply the standard at the time of breach. In modern business practice and modern contract law the metamorphosis into a regime of proximate cause, contractual allocation of loss, and fair disclosure has already begun; to discard the principle of Hadley v. Baxendale would serve the interests of both efficiency and justice.

\section{INTRODUCTION}

In 1854 the Court of Exchequer Chamber decided the now-famous case of Hadley v. Baxendale. ${ }^{1}$ The basic facts are well-known. Briefly, the plaintiffs owned a flour mill that went down because of a break in the crankshaft that worked the mill. As a result, the plamtiffs wanted to transport the broken shaft to the original manufacturer, Joyce \& Co. of Greenwich, to serve as a pattern for the manufacture of a new shaft. They therefore sent an employee to the local office of the defendants, who were large-scale public carriers trading under the name Pickford \& Co. The employee told Pickford's clerk that the mill was stopped and that the shaft must be sent immediately. The clerk answered that if the shaft

$\dagger$ Koret Professor of Law, Boalt Hall School of Law, University of California, Berkeley. A.B. 1956, Columbia University; LL.B. 1959, Harvard University. Daralyn Durie, Mark Ryland, and Daniel A. Saunders provided valuable research assistance for, and comments on, this Article. Several of my colleagues at Berkeley, particularly Einer Elhauge, John Fleming, Gillian Hadfield, Dan Rubinfeld, and Steve Sugarman, also gave me exceptionally helpful comments.

1. 156 Eng. Rep. 145 (Ex. Ch. 1854). 
was sent up by twelve o'clock any day, it would be delivered at Greenwich on the following day.

The shaft was placed in Pickford's hands the next day before twelve o'clock, and Hadley paid $£ 24 \mathrm{~d}$. for its shipment. Pickford's clerk was told that a special entry, if required, should be inade to hasten delivery. In the event, dehvery was delayed for five days "by some neglect":2 Pickford routed the shipment through London and instead of iminediately forwarding the shaft from London to Greenwich by rail, kept the shaft in London for several days and then sent it to Greenwich by canal together with an unrelated shipment of iron goods that Pickford was transporting to Joyce. ${ }^{3}$ Completion of the new shaft by Joyce was correspondingly delayed, and the mill was down five extra days. The plaintiffs claimed that

they thereby were unable to supply many of their customers with flour, sharps, and bran during that period, and were obliged to buy flour to supply some of their other customers, and lost the means and opportumity of selling flour, sharps, and bran, and were deprived of gains and profits which otherwise would have accrued to them, and were unable to employ their workmen, to whom they were compelled to pay wages during that period ....4

On the basis of these claims, the plaintiffs asked for dainages of £300. Pickford argued that the dainages claimed were "too reinote."s The plaintiffs responded that these dainages were "not too reinote, for they are ... the natural and necessary consequence of the defendants' default." The trial court "left the case generally to the jury,"7 which awarded the plaintiffs damages of $£ 25$ above and beyond $£ 25$ that Pickford had already paid into court. The Exchequer Chamber reversed, but not on the theory of reinoteness. Instead, it said that a party injured by a breach of contract can recover only those damages that either should "reasonably be considered . . . [as] arising naturally, i.e., according to the usual course of things" from the breach, or inight "reasonably be supposed to have been in the conteinplation of both parties, at the time they inade the contract, as the probable result of the breach of it."8 The court concluded that the plaintiffs had failed to satisfy either test. ${ }^{9}$ The two branches of the court's holding have coine to be known as the first and second rules of Hadley v. Baxendale.

2. Id. at 147.

3. Richard Danzig, Hadley v. Baxendale: $A$ Study in the Industrialization of the Law, $4 \mathrm{~J}$. LEGAL STUD. 249, 251 \& n.5 (1975).

4. Hadley v. Baxendale, 156 Eng. Rep. at 146.

5. Id. at 147.

6. Id.

7. Id.

8. Id. at 151 .

9. Id. at 151-52. 
Most contracts can be characterized as sales of commodities (using that term broadly to include goods, land, and services) for a money price. The two rules of Hadley v. Baxendale are normally applied only to cases involving a breach by the seller of a commodity, because usually a buyer's inajor obligation is to pay money, and the nonpayment of a money price rarely implicates those two rules. For convenience, in the balance of this Article I shall therefore refer to the party in breach of a contract as the seller and to the party injured by a breach as the buyer. ${ }^{10}$

On the basis of the two rules of Hadley v. Baxendale, contract law has conventionally distinguished between general or direct damages on the one hand and special or consequential damages on the other. General or direct damages are the damages that flow from a given type of breach without regard to the buyer's particular circumstances. General daniages are never barred by the primciple of Hadley v. Baxendale because by their very definition such damages should "reasonably be considered ... [as] arising naturally, i.e., according to the usual course of things from the breach." 11 For example, if a seller breaches a contract for the sale of goods, it follows naturally that the buyer suffers damages equal to the difference between the contract price and the niarket or cover price. This difference can normally be recovered as general damages.

Special or consequential damages are the damages above and beyond general damages that flow from a breach as a result of the buyer's particular circumstances. Typically, consequential daniages ${ }^{12}$ consist of lost profits (although other kinds of consequential damages nray occur). In particular, consequential damages typically consist of the difference between the profits the buyer actually niade in transactions with third persons and the profits he would have inade if the seller had performed. For exaniple, suppose a seller breaches a contract for the sale of a factor of production, such as a die press, that the buyer plans to use rather than resell. The buyer's consequential damages are the difference between the profits he earned on his actual postbreach output and the profits he would have earned if the die press had been furnished as promised.

The second rule of Hadley v. Baxendale has traditionally been con-

10. There are cases in which breacli by a buyer might implicate the rules of Hadley $v$. Baxendale. The analysis in this Article is applicable to sucls cases, although the terminology would liave to be transposed.

11. Hadley v. Baxendale, 156 Eng. Rep. at 151.

12. In this Article, I will use the opposing terms "general" and "consequential damages," althougl this usage involves the adoption of one inember from eacl of two conventionally opposed pairs: "general" froin "general/special," and "consequential" from "direct/consequential." "General" is preferable to "direct" in this context because even consequential damages are usually the direct result of breach. "Consequential" is preferable to "special" because it is more widely used in this context and "special damages" has other meanings in tort pleading and in the law of defamation. 
ceptualized to mean that consequential damages can be recovered only if, at the time the contract was made, the seller had reason to foresee that the consequential damages were the probable result of the breach. ${ }^{13}$ Under this conceptualization of the second rule, the first rule is simply a special case of the second: if a given type of damage arises "naturally, i.e., according to the usual course of things" from the breach of a given contract (the first rule), then a seller will always have reason to foresee that the given type of damages are the probable result of the breach (the second rule). Therefore, in the balance of this Article I will refer to this conceptualization of the second rule as the principle of Hadley $v$. Baxendale.

Two important characteristics of the principle of Hadley $v$. Baxendale should be briefly stated at the outset. First, the principle is a default rule. ${ }^{14}$ Essentially, the principle serves as a device to limit sellers' hability. If the principle were dropped from the law, sellers could still limit hability by contractual provisions that preclude consequential damages, set a dollar or formula limit on hability, offer varying liability limits in exchange for higher or lower prices, or substitute for dollar liability soine other obhigation, such as replacement or repair. ${ }^{15}$ Second, although the principle is often characterized as a "foreseeability doctrine,"16 the principle as traditionally formulated and applied cuts off most foreseeable damages.

This second characteristic of the principle of Hadley v. Baxendale can best be understood by distinguishing among three levels of foreseeability.

The first level is foreseeability im the ordinary sense of that terin, that is, in the sense that an event-here, damage of a certain type-could have been foreseen. In that sense of the term, almost any dainage that actually occurs was likely to have been foreseeable. ${ }^{17}$

A second level of foreseeability requires not only that a certain type of damage could have been foreseen, but that the prospect that this dainage would oceur was more than marginal, or not insignificant. I will use

13. See, e.g., RESTATEMENT (SECOND) OF CONTRACTS $\$ 351$ (1979). The conceptualization of the second rule has varied over time; some alternative conceptualizations are discussed infra note 24 and accompanying text (the "tacit agreement" test); infra Section V.B (the relaxation of the Hadley standard over the last fifty to sixty years).

14. See Ian Ayres \& Robert Gertner, Filling Gaps in Incomplete Contracts: An Economic Theory of Default Rules, 99 YALE L.J. 87, 101-04 (1989).

15. See infra Section V.A.

16. See, e.g., DAN B. DobBs, HaNdBook on THE LAw of REMEdiEs $§ 12.3$, at 804 (1973); Frank H. Easterbrook \& Daniel R. Fischel, Limited Liability and the Corporation, 52 U. CHI. L. REV. 89, 113 n.45 (1985).

17. See Paul L. Joskow, Commercial Impossibility, the Uranium Market and the Westinghouse Case, 6 J. LEgal STUd. 119, 157 (1977) ("In an objective sense, virtually nothing is truly unforeseeable to the extent that theoretically every possible state of the world could be enumerated and some probability assigned to its occurrence."). 
the term reasonably foreseeable to refer to damages that are foreseeable at this second level.

A third and most demanding level of foreseeability requires not only that the damage could have been foreseen, and that the prospect it would occur was more than marginal, or not imsignificant, but that viewed ex ante it was probable or highly probable that the damage wonld result.

The principle of Hadley $v$. Baxendale, as traditionally formnlated and apphied, ratchets up the requirement of foreseeability to the third, exceptionally demanding level, ${ }^{18}$ and thereby cuts off both damages that could have been foreseen and damages that are reasonably foreseeable. Accordingly, it is maccurate, or at least oversimplified, to treat the Hadley principle simply as a foreseeability doctrine. On the one hand, the principle cuts off most foreseeable damages. On the other, a foreseeability limitation would apply in contract law even if the principle of Hadley v. Baxendale were dropped.

The thesis of this Article is as follows: In most areas of law, liability requires a showing only of proximate cause. That primciple, like the primciple of Hadley v. Baxendale, normally turns or should turn on some standard of foreseeability. Therefore, the choice between a regime based on Hadley v. Baxendale and a regime based on proximate cause is not a choice between hability for foreseeable losses and hability for all losses caused in fact. Rather, it is a choice between competing standards of foreseeability, and between competing times for applying the standardthe time when the contract is made or the time when the contract is breached.

As traditionally formulated and apphed, Hadley v. Baxendale reflects three basic choices on these axes: (1) An extremely strict standard of foreseeability, which requires that the damage not be merely foreseeable or reasonably foreseeable, but probable or even highly probable. (2) A uniform standard of foreseeability, regardless of the nature of the interest imvaded and the nature of the breach. (3) An apphication of the foreseeability standard at the time tlie contract is made rather than at the time the contract is breached.

These choices defeat reasonable expectations and fall short in terms of efficiency. Accordingly, the principle of Hadley v. Baxendale should

18. See RESTATEMENT (SECOND) OF CONTRACTS § 351(1) (1979) ("Damages are not recoverable for loss that the party in breach did not have reason to foresee as a probable result of the breach when the contract was made.") (emphasis added); see also Koufos v. C. Czarnikow Ltd. [The Heron II], [1969] 1 App. Cas. 350, 387 (1967) (appeal taken froin Eng.) (opinion of Lord Reid) ("For a considerable time there was a tendency to set narrow himits to awards of damages."); DoBBS, supra note $16, \S 12.3$, at 804-05 ("II]t is clear that what is 'foreseeable' in a tort case may not be foreseeable in a contracts case."); 3 E. Allan Farnsworth, Farnsworth on ConTracts $\S 12.14$, at 240 (1990) ("[A] party in breach is not liable for damages that the party did not at the time of contracting have reason to foresee as a probable result of the breach."); cases cited infra note 26. 
be dropped from contract law in favor of a regime of proximate causeor more accurately, a regime of proximate cause, contractual allocations of loss, and fair disclosure. The precise standard of foreseeability under this regime should depend not on whether the action is labeled contract or tort, but on the nature of the interest invaded and the wrong involved-on whether, for example, the injury involves harm to the person, physical injury to property, lost profits, out-of-pocket costs, or opportumity costs, and on whether the breach was inadvertent or opportunistic. When lost profits or forgone opportunities are involved, the baseline standard should be what I call reasonable foreseeability - that is, whether the prospect that the damage would occur was inore than marginal, or not insignificant. Furthermore, reasonable foreseeability should be determined as of the time of the breach, so that in deciding whether to breach the seller inust sweep into his calculus all the costs that he should reasonably foresee will be incurred by the buyer as a result of breach.

Part I of this Article will examine the close connections between the principle of Hadley v. Baxendale and classical contract law. Part II will compare the principle of Hadley v. Baxendale with the general principle of expectation damages and the principles of damages outside contract law. Part III will examine the modern arguinents for the principle of Hadley v. Baxendale. Part IV will develop the preferable regime of proximate cause, contractual allocations of loss, and fair disclosure. Part $\mathrm{V}$ will show that modern contract law and practice are now moving toward that regime.

I

The Principle of Hadley V. BaXendale and Classical CONTRACT LAW

The principle of Hadley v. Baxendale, although adopted just before the rise of the school of thought we now call classical contract law, proved to fit extraordimarily well with three of the school's tacit premises: that persons would not readily engage in contracting unless their liabihity was narrowly restricted; that contract law could be developed, like geometry, by deduction from axiomatic rules; and that standardized rulesrules whose application is unrelated to the actual intention of the parties or the particnlar facts or circumstances of the transaction-were preferable to individualized rules. ${ }^{19}$

The school of classical contract law tended to einphasize standardization partly because standardized rules can be made to appear axiomatic. Further, the classical school put an extremely strong premium on certainty, and as contract law approaches the limits of standardization so

19. See Melvin A. Eisenberg, The Responsive Model of Contract Law, 36 STAN. L. REV. 1107, 1112-17 (1984). 
too does it approach "that lawyer's Paradise where . . . if the writer has been careful, a lawyer, having a document referred to him, may sit in his chair, inspect the text, and answer all questions without raising his eyes."20

The preference of classical contract law for certainty, hability-limiting devices, and standardized rules led to the adoption of various relatively artificial himits on expectation damages in general and lost profits in particular. For example, during the period of classical contract law the rule that damages had to be proven with an adequate degree of certainty was often apphed to cut off the recovery of lost profits even where a reasonable approximation of lost profits could be made. Under the socalled "new business" rule, the courts made it difficult if not impossible for a new business enterprise to recover any lost profits caused by a breach of contract. ${ }^{21}$ Similarly, in the event a buyer breached a contract for the sale of goods, the seller was generally permitted to recover only standardized damages based on the difference between contract price and market price, not individualized damages based on lost profits. ${ }^{22}$

The principle of Hadley v. Baxendale is of a piece with such hability-limiting devices. Even if apphied in a relatively straightforward way, the principle of Hadley v. Baxendale typically cuts off lost profits and inherently limits damages. Indeed, in Hadley v. Baxendale itself, counsel for Pickford exphicitly argued that the plaintiff's damages should be allocated between the parties rather than compensated by the defendant:

Sedgwick [on Damages] says, ... "In regard to the quantum of damages, instead of adhering to the terin coinpensation, it would be far more accurate to say, in the language of Doinat . . . 'that the object is to discriminate between that portion of the loss which must be borne by the offending party and that which must be borne by the sufferer.' The law, im fact, aims not at the satisfaction but at a division of the loss." And the learned author also cites the following passage from Broom's Legal Maxims: "Every defendant," says Mr. Brooln, "against whom an action is brought, experiences soine injury or mconvenience beyond what the costs will compensate him for."23

During the period of classical contract law the courts often went

20. James B. Thayer, A Preliminary Treatise on Evidence at the Common Law 428-29 (Boston, Little, Brown 1898).

21. See, e.g., Cramer v. Grand Rapids Show Case Co., 119 N.E. 227, 228-29 (N.Y. 1918) ("A distinction exists between the interruption of an established business and a new venture. . . The requirement imposed [on the former] cannot be enforced [on the latter].").

22. See, e.g., Charles St. Garage Co. v. Kaplan, 45 N.E.2d 928, 929 (Mass. 1942).

23. Hadley v. Baxendale, 156 Eng. Rep. 145, 149 (Ex. Ch. 1854); see L.L. Fuller \& William R. Perdue, Jr., The Reliance Interest in Contract Damages, 46 YALE L.J. 52, 84 (1936) ("[Hadley v. Baxendale] may be said to stand for two propositions [the first of which is] that it is not always wise to make the defaulting promisor pay for all the damage which follows as a consequence of his breach."). 
further, manipulatimg the principle of Hadley v. Baxendale to cut off daniages that the principle on its face would seem to allow. In part, this result was achieved by adoption of the "tacit agreement" test. Under that test, consequential daniages could be recovered ouly if the parties had tacitly agreed to the recovery of such daniages at the time the contract was made. ${ }^{24}$ In part, too, this cutoff was achieved by applying the principle of Hadley v. Baxendale in an extremely strict and artificial manner, so as to preclude even consequential daniages the seller had reason to know the buyer would likely mcur. An exaniple is Hadley $v$. Baxendale itself. When the contract in that case was made, the plaintiffs' employee told Pickford's clerk that the mill was stopped and that the shaft must be sent immediately. Certainly any reasonable person in the clerk's position would have thought that these words were related. ${ }^{25}$ The court, however, artificially cut off the plaintiff's dainages by holding, in the face of the facts, that Pickford's was not on notice of the plaintiffs' special circumstances. ${ }^{26}$ The result in the case was at odds with the very

24. See, e.g., Globe Ref. Co. v. Landa Cotton Oil Co., 190 U.S. 540, 544 (1903) (recovery "depends on what liability the defendant fairly may be supposed to lave assumed consciously, or to have warranted the plaintiff reasonably to suppose that it assumed, when the contract was made"); Patrick v. Russo-British Grain Export Co., [1927] 2 K.B. 535, 540 ("[I]f both parties contemplate that the buyer will probably resell and the seller is content to take the risk . . . [this will] support a claim for loss of profit on resale.") (empliasis added); British Columbia \& Vancouver's Island Spar, Lumber \& Saw-Mill Co. v. Nettleship, [1868] 3 L.R.-C.P. 499, 509 (C.P.) ("[T]lie mere fact of knowledge cannot increase liability.").

25. Plaintiffs' counsel futilely argued that if '[a foreseeability] rule is to be adopted, there was ample evidence in the present ease of the defendants' knowledge of such a state of things as would necessarily result in the damage the plaintiffs suffered through the defendants' default." Hadley $v$. Baxendale, 156 Eng. Rep. at 148. Plaintiff' counsel stressed that

[t]here was ample evidence that the defendants knew the purpose for which this shaft was sent, and that the result of its nondelivery in due time would be the stoppage of the mill; for the defendants' agent, at their place of business, was told that the mill was then stopped, that the shaft must be delivered immediately, and that if a special entry was necessary to hasten its delivery, such an entry should be made.

Id. at 149.

26. In Victoria Laundry (Windsor) Ltd. v. Newman Indus. Ltd., [1949] 2 K.B. 528 (Eng. C.A.), Lord Justice Asquith stated that the headnote and statement of facts in Hadley v. Baxendale must lave been incorrect

in so far as it says that the defendant's clerk, who attended at the office, was told that the mill was stopped and that the shaft inust be delivered immediately. ... If the Court of Exchequer liad accepted these facts as estabhished, the court must ... have held the damage claimed was recoverable under the second rule.

Id. at 537. Asquith here seems to have had his tongue in lis cheek, although it is true that the court in Hadley did say at one point,

Now, in the present case, if we are to apply the principles above laid down, we find that the only circumstances here communicated by the plaintiffs to the defendants at the time the contract was made, were, that the article to be carried was the broken shaft of a mill, and that the plaintiffs were the millers of that mill.

Hadley v. Baxendale, 156 Eng. Rep. at 151.

Another interpretation of Hadley v. Baxendale is that relief was denied because the court effectively required that damages be not ouly probable but highly probable. That condition was not satisfied, in the view of the court, because Pickford "did not know that unreasonable delay on their 
rules the court laid down.

The principle of Hadley v. Baxendale also reflected the preference of classical contract law for standardized rules, because it tended to substitute the standardized damages that would have been incurred by a standardized individual or firm for the actual damages incurred by a real individual or firm. ${ }^{27}$ Victoria Laundry (Windsor) Ltd. v. Newman Industries $L t d .{ }^{28}$ illustrates the extent to which standardization could be carried. Victoria Laundry was in the laundry and dyeing business. It owned a boiler whose capacity was $1500-1600$ pounds evaporation per hour, but it wanted a boiler of inuch greater capacity so that it could expand its business. In April 1946, Victoria contracted to buy froin Newinan a used boiler with a capacity of 8000 pounds per hour, at a price of $£ 2150$, loaded f.o.b. at Newinan's premises, delivery on June 5. Newman employed a third person, $T$, to dismantle the boiler. On June 1, $T$ damaged the boiler in the process of dismantling it. As a result, Victoria did not receive delivery until Novernber 8 , and sued Newman for lost profits during the period from June 5 to Noveinber 8. Victoria claimed that if the boiler had been timiely delivered on June 5, during the period from June 5 to Noveinber 8 it would have accepted "highly lucrative"29 dyeing contracts for the Mimistry of Supply. The resulting loss of profits was stated to be $£ 262$ per week. ${ }^{30}$ The court held that Victoria could not recover its actual (individualized) lost profits under the lost Mimistry of Supply contracts uuless the seller was on notice at the time the contract was formed of the prospect and terins of those contracts, but that Victoria could recover "soine general [standardized] . . . sum for loss of business in respect of dyeing contracts to be reasonably expected." 31

Finally, the rules of classical contract law tended to have a static quality, and the principle of Hadley v. Baxendale proved a good fit with this quality of classical contract law as well. Under Hadley, the seller's liability was determined by what he knew or should lave known at the

part would result in the loss since the millers might have had another shaft or their machinery might have been out of order for some other reason." H.L.A. HART \& TONY HONORE, CAUSATION IN THE LAW 319 (2d ed. 1985).

For other examples of an artificially strict application of the principle of Hadley v. Baxendale to cut off reasonably foreseeable damages, see McMillam Lumber Co. v. First Nat'1 Bank, 110 So. 602 (Ala. 1926); F \& B Ceco, Inc. v. Galaxy Studios, Inc., 201 So.2d 597 (Fla. Dist. Ct. App. 1967); Marcus \& Co. v. K.L.G. Baking Co., 3 A.2d 627 (N.J. 1939); Czarnikow-Rionda Co. v. Federal Sugar Ref. Co., 173 N.E. 913 (N.Y. 1930); Keystone Diesel Engine Co. v. Irwin, 191 A.2d 376 (Pa. 1963), overruled by R.I. Lampus Co. v. Neville Cement Prods. Corp., 378 A.2d 288 (Pa. 1977); Longview Constr. and Dev., Inc. v. Loggins Constr. Co., 523 S.W.2d 771 (Tex. Civ. App. 1975); Head \& Guild Equip. Co. v. Bond, 470 S.W.2d 909 (Tex. Civ. App. 1971).

27. See Danzig, supra note 3 , at 278 (discussing standardization of damages).

28. [1949] 2 K.B. 528 (Eng. C.A.).

29. Id. at 535 .

30. Id.

31. Id. at 543; accord RESTATEMENT (SECOND) OF CONTRACTS $§ 351 \mathrm{cmt}$ b (1979). 
time of contract formation, so that he could shut his eyes to circumstances that developed in the course of time and performance and to information communicated after the contract was nade. The principle therefore conceived of contracts as lacking, for hability purposes, any capacity for dynamic change with respect to circunistances unfolding after contract formation. The tacit agreenient test was a particularly dramatic example of this conception.

II

\section{The General Principle of Expectation Damages and the Principles of Damages OUtSIDE CONTRACT LAW}

If it is easy to see why the principle of Hadley v. Baxendale was appealing to the school of classical contract law, it is much harder to see why it should be appealing now that the restrictive premises of the classical school are no longer accepted. An examination of that question can profitably begin by considering the divergence between the special principle of Hadley v. Baxendale, on the one hand, and both the general principle of expectation damages and damage principles outside contract law, on the other.

\section{A. Expectation Damages}

The general principle of expectation damages is that the victim of a breach of contract is to be put in the position he would have been in had the contract been performed. In contrast, the special principle of Hadley v. Baxendale often leaves the victim far short of the position he would have been in if the contract had been performed. Of course, it might be argued that the general principle of expectation damages is itself undesirable. Such a position seenied tacitly to underhe the approach of classical contract law to such issues as the certainty with which dainages nuust be proved, the recovery of sellers' lost profits, and indeed the principle of Hadley v. Baxendale itself. ${ }^{32}$ Certainly the case for expectation damages

32. Some modern scholars have also argued against expectation damages. See, e.g., Richard Epstein, Beyond Foreseeability: Consequential Damages in the Law of Contract, $18 \mathrm{~J}$. LEGAL STuD. 105 (1989). Epstem argues against expectation damages on the ground that many contracts limit liability to an amount less than expectation damages, and therefore parties must prefer limited hability to expectation damages. The argument, which is specifically extended to the principle of Hadley v. Baxendale, is not justified by the empirical data upon which Epstein relies. Under present law, the default rule is that expectation damages will be awarded on breacl. As a result, contracting parties who prefer expectation damages need not insert a provision to that effect, but contracting parties who do not want expectation damages must insert such a provision. Therefore, even if the great majority of parties preferred expectation damages, tlic great majority of contractual-damage provisions would provide for some otler measure. Ayres and Gertner put this well:

[S]ome commentators liave suggested that courts [should] fill gaps [in contracts] with thc provisions that most parties bargain for in actual contracts. Some academics have labelled 
is not self-evident, but it can be shown that the principle of expectation damages, if properly administered so as not to encourage overreliance, ${ }^{33}$ is botli efficient and fair.

Contracts are norinally made for the purpose of mutual gain. Under ideal bargaining conditions (that is, where negotiation and drafting are cost-free), the bargaining process maximizes the value that a contract creates. A damage rule therefore norinally can be deemed botli efficient and fair if it corresponds to the terins that similarly situated parties would liave reaclied if bargaining under such conditions. ${ }^{34}$ Parties bargaining under ideal conditions miglit consider a number of dimensions in deterınining tlie most appropriate damage measure. I will focus liere on the effect of expectation damages on the rates of perforinance, precaution, contract forination, and reliance. ${ }^{35}$

\section{Rate of Performance}

The imcentive to make contracts depends on the reliability of contracts. Accordingly, one highly important dimension of a damage measure concerns its incentive effects on the rate of perforinance-that is, on decisions whetlier to perforin or breacli executory contracts. A contract involves a promise by at least one party. It is always possible that events will induce a promisor to refuse to perform, eitlier because perforinance has become unprofitable or because a newly presented alternative perfornance is more profitable. From this perspective, the attraction of expectation dainages is that tliey place on the breaching party the loss of the other party's share of the contract's value, and thereby sweep that loss into each party's self-mterested calculus in a decision whether to

this style of gap-filling as "mimicking-the-market." The mimic-the-market approach to default rules ignores the fact that the type of parties who contract around a given rule depends upon the rule itself. Parties who dislike a given default rule will contract around it; if we change the default rule to mimic the contraets these parties write, other types of parties may contract around the new default back to the original rule. This process could cycle forever.

Ayres \& Gertner, supra note 14, at 115 (footnotes omitted).

In addition, many contracts that Epstein takes to limit liability actually set out a menu under which the buyer trades off price and liability. Inspection of such contracts will often not reveal whether the hability level that the buyer chose is lower, higher, or the same as the damages that would have been awarded in the absence of the choice. Finally, Epstein disregards the thousands of contracts with liquidated-damage provisions, most of which probably extend rather than limit the liability that would be imposed $\mathrm{m}$ the absence of the provision.

33. See infra text accompanying note 37.

34. Ayres and Gertner demonstrate that in soine cases the choice of a default rule should be based on other grounds. In particular, the choice should sometimes be based on whether a given rule will induce one prospective contracting party to reveal certain kinds of information to another who is less informed. Ayres \& Gertner, supra note 14, at 97-100, 108-18. In general, however, the choice of basic remedial rules probably would not fall within such an exception, although some secondary rules might be best selected in that way.

35. The following passages draw on Robert Cooter \& Melvin A. Eisenberg, Damages for Breach of Contract, 73 CALIF. L. REV. 1434 (1985). 
perform or to breach. In contrast, if liability was not based on expectation damages, the value of a contracted-for performance to one party would not enter into the otlier's purely self-interested calculation whetler to perform or breach.

This analysis can be restated in terms of externalities. Incentives for performance are efficient if they compel a party to balance the cost he will mcur if he performs against the losses he and the other party will incur if he does not perform. Contracts create value. If one party to a contract breaches, then the other party will suffer a loss of his share of that value unless the expectation measure is einployed. If a party who breaches is liable for the otlier party's loss (or reasonably foreseeable loss) of his share of the value created by the contract, then in determining whether to perform or breach he will internalize not only his own loss, but the losses of the other party as well. Expectation damages therefore create efficient incentives for performance.

By directly affecting the probability that contracting parties will perform, the expectation measure lias indirect effects upon beliavior as well. These effects can be stated in terms of planning. Parties often enter into contracts to stabilize certain elements in a changing world-or, to put it differently, to put some elements of the world to rest, so that the remaining elements can be dealt witl from a stable foundation. A measure of dainages that is equivalent to the value of performance furtliers the objective of stabilization. A contracting party, knowing that expectation damages give an adequate incentive to perform, will be more confident that his reliance on the terms of the contract will not expose him to undue risk. Accordingly, each contracting party can plan inore reliably, and therefore more effectively, because lie can order his affairs with confidence that lie will realize the contract's value. Moreover, it is in each party's interest that the other be able to plan rehably because the ability to do so, and thereby realize the value of the contract, will render eacli party willing to pay a higher contract price.

These ideas can also be expressed in institutional terms. The purpose of the social institution of bargam is to create joint value through exchange. In recoginition of the desirability of creating value in this manner, the legal institution of contract supports the social institution of bargam by providing official sanctions for breacl. It is rational to design the legal sanctions so that the joint value from excliange is naximized. This goal is aclieved by expectation damages.

\section{Rate of Precaution}

One reason breacli might occur is that a contract has become unprofitable to the breaching party due to an increase in lis cost of performance. Another reason for breach is that changed circumstances 
have made performance unduly costly or difficult, although there is no legal excuse for nonperformance. In some such cases, the breaching party might have forestalled the motivation for breach if he had taken appropriate precautions against the change in cost or circumstances. For example, a seller might order materials well im advance to protect agamst the possibility of a price rise or might hire extra workers to protect against the possibility that a critical employee could quit or fall ill. Precaution is usually costly in terms of money or effort. From an efficiency standpoint, however, this cost must be balanced agamst the resulting benefit- $a$ reduction $m$ the probability of breach and a consequent enhancement of the likelihood that the value of the contract will be realized.

The expectation measure provides an incentive for the efficient amount of precaution for the same reason that it provides an incentive for the efficient rate of performance. An incentive for precaution is efficient if it imduces each party to balance the cost of precaution agamst the cost of failing to take precaution, including the risk to the other party of losing his share of the contract's value. In the absence of liability for expectation damages, that risk would not enter into a purely self-interested calculation, and the incentive for precaution would therefore be inadequate. Expectation damages cause each party to imternalize the cost of failure to take adequate precaution, and therefore create an incentive for efficient precaution against breach.

\section{Rate of Contract Formation}

Anotlier dimension of a damage measure concerns its effect on the rate of contract formation. There would be little incentive to make contracts if costs resulting from the other party's breach were not compensable. Therefore, the minimum damage measure to whicl contracting parties would normally agree is a rehance or cost measure, based on the parties' baseline reliance interests. Rehance, however, is often difficult to prove. Furthermore, even if the fact of reliance is proved, reliance damages can be difficult to measure, particularly when the rehiance consists of opporturity costs resulting from passive inaction (such as failure to pursue alternatives) rather than from a positive change of position. Accordimgly, bargaming parties who address the issue of what damage measure they will require if they are to contract might select an expectation measure not only because that measure will provide efficient incentives for performance and precaution, but also because the ease of admimistering that measure ensures protection of the baseline reliance interest. ${ }^{36}$

36. But see David D. Friedman, An Economic Analysis of Alternative Rules for Breach of Contract, 32 J.L. \& ECON. 281 (1989). Friedman argues against expectation damages on the ground 


\section{Rate of Reliance}

A remaining dimension of a damage measure relevant to its efficiency is whether the measure provides an incentive for "overreliance," that is, for inefficient reliance. Reliance on a contract by a buyer can take several forms. One form of reliance consists of performing the contract. The extent of this form of reliance does not pose significant efficiency issues, because the very object of a contract is to commit the parties to perform.

Another form of reliance consists of forgoing other opportunities. The extent of this form of reliance also does not pose significant efficiency issues, because if a seller's contracts were not rehable enougli at least to induce the buyer to forgo otler opportunities, they would not be worth enterimg into.

Still a third form of reliance consists of actions that are not required for performance under the contract, but will enable the relying party to gain increased value from the contract. For example, a buyer who has contracted to purchase a yacht might buy special navigational equipment in advance of delivery in order to take transoceanic trips as soon as the boat is delivered, ratlier than postponing enjoyment of such travel by awaiting dehivery of the yacht before ordering the special equipment. This type of reliance is sometimes referred to as "beneficial reliance."

Because not all contracts are performed, it can be argued that it is inefficient for a contracting party to engage in beneficial reliance beyond the extent to which the reliance will likely be profitable given the probability of nonperformance. ${ }^{37}$ However, expectation damages do not

that a damage measure that is based on a seller's contract price, rather than its costs of production, might result im an inefficient rate of contract formation when price exceeds cost.

[The efficient rule for the decision] to buy or not to buy ... is to buy if the value of a unit of the good to the consumer is greater than the cost of producing it. The rule the consumer will follow, however, is to buy if the value is greater than the price. This inefficiency is the traditional economic argument against monopoly. If the price were not greater than the cost of production, expectation and reliance rules would yield the same result, so the imefficiency of monopoly pricing is intimately related to the evaluation of the two rules.

Id. at 285. Accordingly, Friedman maintains, a producer's damages should often (although not always) be based on cost rather than on price, even in competitive markets. Friedinan's argument depends, however, on the assumption that "the court[s] can costlessly measure the producer's costs." Id. at 282. There is no world in which that assumption holds, and Friedman's approach would turn every contracts case into a regulated-industry proceeding. Furthermore, except in the case of a producer who has a pure monopoly over a commodity for which there are no good substitutes, Friedman's approach departs from basic concepts of fairness, which suggest that a buyer in a competitive marketplace, who obtains a commodity for which rcasonable substitutes are available by pronising to pay the competitive market price, cannot fairly complain about paying the price after the producer has delivered the commodity in exchange for the promise. Finally, Friedinan's approach would have serious efficiency probleins because a rule that often made contract danages depend on cost rather than price would induce producers to sell only to those buyers who made advance payment, and would therefore seriously disrupt the utility of contracts.

37. See Robert Cooter, Unity in Tort, Contract, and Property: The Model of Precaution, 73 
inherently provide an incentive for this form of overrehance. Although beneficial reliance by a victim of breach can result in the addition of reliance damages to expectation damages, the calculation of expectation damages itself should be, and normally is, invariant to beneficial reliance.

For example, general damages for the seller's breacli of a contract for the sale of goods is the difference between the contract price and the cover or market price of the goods. These measures are invariant to the buyer's beneficial reliance. Similarly, general damages for the buyer's breach of such a contract are measured by the difference between the contract price and either tlie resale or inarket price of the goods or the seller's variable costs of production. These measures are essentially invariant to the seller's beneficial reliance. In theory, certain elements of expectation damages might partly depend on beneficial reliance in some cases-for example, in cases in which a victim of breach seeks to recover lost profits under other contracts that the victim made in rehance that the original contract would be fulfilled. In practice, the prospect of actual and ineasurable overrehiance in cases of this sort seeins slim enough to disregard, but if the prospect is deeined significant, it can be addressed inost directly simply by disallowing the extent of unreasonable reliance as an element of expectation damages.

\section{B. Damage Principles Outside Contract Law}

The special principle of Hadley v. Baxendale diverges not only froin the general principle of expectation dainages but froin tlie general primciples of damages outside the law of contract. As traditionally formulated, the principle of Hadley v. Baxendale cuts off damages that are caused by a wrongful breach unless the seller had reason to foresee, at the time of contract formation, that the damages would be the probable result of breach. ${ }^{38}$ Outside the law of contract, lowever, once it has been estabhished that $A$ has violated a duty to $B, B$ is normally entitled to compensation for all damages proximately caused by $A$ 's wrongful act. ${ }^{39}$ The principle of proximate cause, like the principle of Hadley v. Baxendale, nornally turns on foreseeability, but foreseeability in proximate cause is ineasured at the time of the wrong and does not require that the damages were the probable result of the wrong. ${ }^{40}$

The concept that damages are determined under the primciple of

CALIF. L. REv. 1, 13-14 (1985) (arguing that the reasonability of reliance should be a function of the likelihood of the breach).

38. See, e.g., authorities cited supra note 18.

39. See, e.g., U.C.C. $\$ 2-714(1990)$ (damages for breach of warranty governed by the principle of proximate cause); Grant Gilmore \& CharLes L. Black, JR., The LAW of AdMiralty 76 (1975) (marine insurance covers losses "proximately caused" by the peril insured against and claimed under).

40. See infra notes $48-53,84-86$ and accompanying text. 
proximate cause runs through the law, but is most salient in tort. The divergence between the scope of damages im contract and tort is therefore especially notable. In 1961, the Enghish Privy Council, im Overseas Tankship (U.K.) Ltd. v. Morts Dock \& Engineering Co. [The Wagon Mound $I],{ }^{41}$ flirted briefly with a unification of the scope of tort and contract damages through the substitution of the principle of Hadley $v$. Baxendale for the principle of proximate cause. Morts Dock Company was in the busmess of ship-repairing at a timber wharf it owned in Morts Bay in the Port of Sydney. The vessels Corrimal and Audrey $D$ were moored at the wharf undergoing repairs. At the same time, the vessel Wagon Mound, chartered by Overseas Tankship, was being refueled at a wharf about 600 feet away. Through the carelessness of Overseas employees, a large quantity of bunkering oil from the Wagon Mound was allowed to spill, and the oil soon spread in the bay. Overseas made no attempt to disperse the oil because it beheved that oil floating on water could not catch fire. Morts also concluded that it could operate safely despite the oil, but directed that all safety precautions should be taken to prevent flammable material from falling off the wharf. However, molten metal fell froin the wharf onto debris covered with cotton waste, the cotton waste burst into flames, the flames set the floating oil on fire, and the fire severely damaged the wharf. The Privy Council held that Overseas was not hable to Morts, rejected the well-known Polemis case $\mathrm{e}^{42}$ in which the defendant was held hable for a fire that resulted when a plank fell into a ship's hold, and suggested that Hadley v. Baxendale might govern tort as well as contract damages. ${ }^{43}$

This position was soon abandoned im a pair of notable tort and contract cases. The tort case was Overseas Tankship (U.K.) Ltd. v. Miller Steamship Co. [The Wagon Mound II]. ${ }^{44}$ This case arose out of the same fire as Wagon Mound I, but was brought by the owners of the Corrimal and the Audrey $D$. In deciding this case, the Privy Council did one and a half pirouettes and held Overseas hable on the ground that a reasonable person cannot neglect a risk that he ought to know is real, even if of very small magnitude, unless there is some valid reason for doing so. ${ }^{45}$ In the

41. 1961 App. Cas. 388 (P.C.) (appeal taken from N.S.W.).

42. In re Polemis, [1921] 3 K.B. 560 (Eng. C.A.).

43. The Wagon Mound I, 1961 App. Cas. at 419.

44. 1967 App. Cas. 617 (P.C. 1966) (appeal taken from N.S.W.).

45. Id. at 642. The court rationalized the divergent outcomes in Wagon Mound I and Wagon Mound $I I$ as follows:

The plaintiffs [in Wagon Mound I] were no doubt embarrassed by a difficulty which does not affect the present plaintiffs. The outbreak of the fire was consequent on the act of the manager of the plaintiffs in [Wagon Mound I] in resuming oxy-acetylene welding and cutting while the wharf was surrounded by this oil. So if the plaintiffs in the former case had set out to prove that it was foreseeable by the [defendant's] engineers ... that this oil could be set alight, they might have had difficulty in parrying the reply that this must also have been foreseeable by their manager. Then there would have been contributory 
course of its opinion, the House of Lords cast considerable doubt on the suggestion that the principle of Hadley v. Baxendale should be apphed in the law of torts. ${ }^{46}$

The contract case, decided a year later, was Koufos v. C. Czarnikow Ltd. [The Heron II]. ${ }^{47}$ A carrier had agreed to transport 3000 tons of sugar for a shipper from Constanza to Basrah. The shipper's intention was to sell the sugar proinptly after arrival at Basrah. The vessel should have arrived in Basrah on November 22, but in breach of contract the carrier made deviations in the journey and the vessel did not arrive in Basrah until December 2. Shortly before that tinie, the market price of sugar im Basrah had fallen, partly because of the arrival of another cargo of sugar, and the shipper sued the carrier for the shortfall. Lord Reid's opinion is particularly straightforward in demonstratimg that as traditionally formulated and apphed, the principle of Hadley v. Baxendale, unlike the principle of proximate cause, is not a test of reasonable foreseeability:

[In Hadley v. Baxendale] Alderson B. clearly did not and could not mean that it was not reasonably foreseeable that delay might stop the resumption of work in the mill. He merely said that in the great multitude-which I take to mean the great majority-of cases this would not happen. He was not distinguishing between results which were foreseeable or unforeseeable, but between results which were likely because they would happen in the great majority of cases, and results which were unlikely because they would only happen in a small minority of cases.... He clearly meant that a result which will happen in the great majority of cases should fairly and reasonably be regarded as having been in the contemplation of the parties, but that a result which, though foreseeable as a substantial possibility, would only happen im a small minority of cases should not be regarded as having been in their contemplation. . . .

I am satisfied that the court did not intend that every type of damage which was reasonably foreseeable by the parties when the contract was inade should either be considered as arising naturally, i.e., in the usual course of things, or be supposed to have been in the contemplation of the

negligence and at that time contributory negligence was a complete defence in New South Wales.

Id. at $640-41$ (citations omitted).

46. The court said:

The appellant's first argument was that damages depend on the same principles throughout the law of tort and contract. This was stated emphatically by Lord Esher in The Notting Hill and in The Argentino and it has often been repeated. But the matter has not been fully investigated recently. There has in recent times been inuch development of the law of tort and developments in the law of contract may not havc proceeded on parallel lines.

Id. at 638 (citations omitted).

47. Koufos v. C. Czarnikow Ltd. [The Heron II], [1969] 1 App. Cas. 350 (1967) (appeal taken from Eng.). 
parties. Indeed the decision [in Hadley] makes it clear that a type of damage which was plainly foreseeable as a real possibility but which would only occur in a small minority of cases cannot be regarded as arising in the usual course of things or be supposed to have been in the contemplation of the parties: the parties are not supposed to contemplate as grounds for the recovery of damage any type of loss or damage which on the knowledge available to the defendant would appear to him as only likely to occur in a small minority of cases.

...

The modern rule of tort is quite different and it imposes a much wider hability. The defendant will be hable for any type of damage which is reasonably foreseeable as hable to happen even in the most unusual case, unless the risk is so small that a reasonable man would in the whole circumstances feel justified in neglecting it. . . . I have no doubt that today a tortfeasor would be held hable for a type of damage as unlikely as was the stoppage of Hadley's Mill for lack of a crankshaft: to anyone with the knowledge the carrier had that may have seemed unlikely [and therefore not within the principle of Hadley v. Baxendale] but the chancc of it happeming wonld have been seen to be far froin negligible [and therefore within the principle of proximate cause]. But it does not at all follow that Hadley v. Baxendale would today be differently decided. ${ }^{48}$

American law has also traditionally recognized the divergence between the general principle of proximate cause and the special principle of Hadley v. Baxendale. For example, in Petition of Kinsman Transit Co., ${ }^{49}$ as a result of the defendants' neghgence, the vessel MacGilvray Shiras broke loose from her moorings and careened stern first down a river channel. She struck another vessel, which in turn broke loose from her moorings and drifted downstream, followed by the Shiras, until they both crashed into a bridge. The bridge collapsed, and the wreckage formed a dam that caused extensive flooding and an ice jam reaching almost three miles upstream. The Second Circuit, in a notable opinion by Judge Friendly, upheld the hability of the defendants for damages resulting directly from the collisions and the upstream flooding and cited with approval a Minnesota ruling "that the rule of Hadley v. Baxendale

48. Id. at 384-86 (citation omitted). In H. Parsons (Livestock) Ltd. v. Uttley Ingham \& Co., [1978] 1 Q.B. 791 (Eng. C.A. 1977), Lord Denning summarized The Heron II as follows:

In the case of a breach of contract, the court has to consider whether the consequences were of such a kind that a reasonable man, at the time of making the contract, would contemplate them as being of a very substantial degree of probability. . . .

In the case of a tort, the court has to consider whether the consequences were of such a kind that a reasonable man, at the time of the tort committed, would foresee them as being of a much lower degree of probability.

Id. at 801-02 (opinion of Lord Denning, M.R.).

49. 338 F.2d 708 (2d Cir. 1964), cert. denied, 380 U.S. 944 (1965). 
has no place in negligence law."so Similarly, the Restatement (Second) of Torts permits the recovery of all damages when the defendant's conduct is a substantial factor in bringing about the harm, as long as the result was not "highly extraordinary." In contrast, the Restatement (Second) of Contracts provides that "[d] amages are not recoverable for loss that the party in breach did not have reason to foresee as a probable result of the breacli when the contract was made,"52 and the cases under Hadley v. Baxendale traditionally applied that or even stricter standards. ${ }^{53}$

To summarize, the special principle of Hadley v. Baxendale, as traditionally fornulated and apphed, diverges from both the general principle of expectation damages and the general principles of damages outside the law of contract. If those general principles are desirable, the special principle of Hadley v. Baxendale must then be undesirable unless it can be supported by some special justification. I will now consider the leading modern arguments that attempt to show tliat such a justification exists.

III

The Modern Arguments for the Principle of HADLEY V. BAXENDALE

\section{A. The Least-Cost Argument}

One argument for the principle of Hadley v. Baxendale is based on least-cost theory. This argument takes several forins. In one forn, the argunent is based on the effect of the principle of Hadley v. Baxendale on precontract conduct. For example, in EVRA Corp. v. Swiss Bank Corp. ${ }^{54}$ Judge Posner stated:

[T] he animating principle of Hadley v. Baxendale ... is that the costs of the untoward consequence of a course of dealings should be borne by that party who was able to avert the consequence at least cost and failed to do so. In Hadley the untoward consequence was the shutting down of the mill. The carrier could have avoided it by dehivering the engine shaft on time. But the mill owners, as the court noted, could have avoided it simply by having a spare shaft. Prudence required that they have a spare shaft anyway, since a replacement could not be obtained at once even if there was no undue delay in carting the broken shaft to and the replacement shaft from the manufacturer. The court refused to imply a duty on the part of the carrier to guarantee the mill owners against the consequences of their own lack of prndence, though of course if the parties had

50. Id. at 724 (citing Christianson v. Chicago, St. P., M. \& O. Ry., 69 N.W. 640, 641 (Minn. 1896)).

51. RESTATEMENT (SECOND) OF TORTS $\$ 435$ (1964).

52. REsTATEMENT (SECOND) OF CoNTRACTS § 351(1) (1979).

53. See DoBBS, supra note $16, \S 12.3$, at $804-05$ (1973); cases cited supra note 26.

54. 673 F.2d 951 (7th Cir.), cert. denied, 459 U.S. 1017 (1982). 
stipulated for such a guarantee the court would have enforced it. The notice requirement of Hadley v. Baxendale is desigued to assure that such an improbable guarantee really is intended. ${ }^{55}$

This argument fails to justify the principle of Hadley v. Baxendale. In most cases involving consequential damages it can be assumed that the buyer has acted prudently during the period before the contract was made, because reasons of self-regard will have led him to do so. Under Posner's argument, prudence would require every factory owner to carry the spare parts for a virtually coinplete factory, housed alongside his operating factory. In fact, however, calculations concerning the optimum supply of spare parts are enormously complex and must reflect the probability that parts will fail, the cost of waiting for needed spare parts that are not kept in mventory, the cost of capital employed in mvesting in spare parts, the cost of mamtaining spare parts, and the actual or imputed rental costs for storing spare parts. There is hittle or no reason to beheve either that the mill owner in Hadley v. Baxendale failed to maintain an optimum supply of spare parts im the period before the crankshaft broke or that under a less demanding foreseeability standard imdividuals or firms would generally fail to optimize just because they 1might later enter into a contract.

A second form of the least-cost argument concerns the period between the time the contract is made and the time of breach. For example, in his book Economic Analysis of Law, ${ }^{56}$ Posner argues:

Consider the following variant of the facts in [Hadley v. Baxendale]. A commercial photographer purchases a roll of film to take pictures of the Himalayas for a magazime. The cost of developing the film is included in the purchase price. The photographer mcurs heavy expenses (including the hire of an airplane) to complete the assignment. He mails the film to the manufacturer but it is mislaid $m$ the developing room and never found.

Compare the mcentive effects of allowing the photographer to recover his full losses and limitimg him to recovery of the price of the film. The first alternative creates few-maybe no-imcentives to avoid similar losses in the future. The photographer will take no precautions; he will be indifferent between the successful completion of his assigument and the receipt of full compensation for its failure. The manufacturer of the film will probably take no additional precautions either, because he cannot identify the films whose loss would be extremely costly, and unless there are many of them it may not pay to take additional precautions on all the films he develops. The second alternative, in contrast, should mduce the photographer to take precautions that turn out to be at

55. Id. at 957 (citation omitted). Posner repeated this argument in Afram Export Corp. v. Metallurgiki Halyps, S.A., 772 F.2d 1358, 1368 (7th Cir. 1985) and in Rardin v. T \& D Machine Handling, Inc., 890 F.2d 24, 27 (7th Cir. 1989).

56. Richard A. Posner, Economic ANalysis of LAW (3d ed. 1986). 
once inexpensive and effective: Using two rolls of film or requesting special handling when he sends the roll in to be developed. ${ }^{57}$

This argument concerns a special form of overrehance, that is, the extent to which a buyer can reasonably rely on the prospect of performance by the seller. Posner seems to assume that virtually no reliance is prudent. Under Posner's analysis, presumably the pliotographer would not act prudently unless he took duplicate pictures, used film of duplicate manufacturers, used duplicate cameras, entrusted one roll of film to the mails and the other to a private dehivery service, and so fortl. In fact, however, such beliavior would not be prudent, but compulsive. (Of course, the direct cost of some items, such as film, may seem relatively small, bnt the direct and indirect costs of doubling the number of plotographs would be very large.)

Furthermore, Posner's analysis seeins to assume that the rate of breacl is relatively high. Perhaps a higl rate of breacl would make it prudent for a buyer to double up on every action, althougli even that seems doubtful. Certainly, however, prudence does not require doubling up when the rate of breach is very low, as it normally is. ${ }^{58}$ Although Posner argues that allowing the plotograplier to recover his full losses would create few or no incentives to avoid similar losses in the future, no rational person regards a liability claim as a satisfactory substitute for performance. If the photograplier thinks there is a significant likelihood of breacli by a contractor, self-interest will drive him to double up whetlier the contractor is liable or not. It is for this reason tliat overreliance is unlikely to be a problem in the real world or, at least, is likely to be too marginal to serve as an important basis for legal rules. In any event, as pointed out above, ${ }^{59}$ if the prospect of overreliance is deemed significant it slould be directly addressed by disallowing the extent of unreasonable reliance as an eleinent of expectation damages.

In this connection, it is striking that Posner would make the seller fully liable even if the photographer sliot only one roll of film, if the seller had been put on notice before or after the contract was made. Sucli notice, however, would be irrelevant to the reasonability of the pliotographer's conduct. If it is imprudent to shoot only one roll of film without having given notice under Hadley, it is also imprudent to shoot only one roll even if notice is given, and particularly if notice is given only after the fact.

A third form of the least-cost argument is that buyers may act imprudently during the period after breacli occurs, by failing to take lowcost measures that would minimize the loss because they hope that the

57. Id. at 114 .

58. See infra text accompanying note 77 .

59. See supra text accompanying note 37 . 
loss will fall on the seller. EVRA Corp. v. Swiss Bank Corp. was just such a case. The defendant was a bank that had neghigently failed to complete a transfer of funds. That failure caused the plaintiff to lose his rights under a valuable contract with a third party, but the plaintiff could have inexpensively protected his rights under the contract by wiring a replaceinent payment when he learned that the original fund transfer had not been made. However, cases in which a buyer acts imprudently after the breach, by failing to minimize the loss, do not justify the principle of Hadley v. Baxendale, because they are better addressed by the more basic principle of mitigation of dainages.

In short, least-cost theory does not justify the principle of Hadley $v$. Baxendale because in the period before breach a buyer will optimize his conduct for reasons of self-regard, and in the period after breach the poimt of the least-cost argument is better captured by the principle of danage mitigation.

\section{B. The Theory of Efficient Breach}

Another efficiency argument that is sometimes used to justify the principle of Hadley v. Baxendale is based on the theory of efficient breach. This theory suggests that breach of contract should be tolerated or even encouraged when the mutual gain resulting from the breach exceeds the mutual loss. Broadly speaking, this theory corresponds to the argument for expectation dainages based on the efficient rate of performance, because both concepts are based on the idea that a party contemplating breach should sweep into his calculus not only his own gains and losses but those of the other party. Richard Danzig offers the following illustration that suggests a relationship between the theory of efficient breach and the principle of Hadley v. Baxendale:

[C]onsider the position of a truck owner, $A$, who has a contract to sell his truck to $B$, and assume that $B$ would suffer a "normal" net loss of $\$ 200$ if the truck were not made available as scheduled. If $C$ arrives on the scene and bids to preempt the truck for an urgent need, $A$ can estimate the damages he will "normally" owe $B$. He will presumably sell to $C$ only if the new sale price will exceed the old sale price plus $\$ 200$ in damages. If $C$ is willing to buy for such a high price, it is to everybody's advantage to let him do so. $C$ benefits because he values the truck more highly than he values the money he is paying for it; $B$ benefits because he receives his expected profits by way of damages; $A$ benefits because he makes more money, even after paying damages than he would have made had the truck not been sold to $C$. Society benefits because one party, $C$, has gained while no other party has lost. If $B$ were in an abnormal situation and so expected to suffer greater damages than $\$ 200$, the rule of Hadley v. Baxendale would coerce him into signaling these higher damages, so that the proper damage calculation and subsequent truck alloca- 
tion would be made. Thus, in theory, by facilitating an accurate calculus of breach, the rule optimizes resource allocation. ${ }^{60}$

An analysis of this illustration shows that the theory of efficient breach fails to justify the principle of Hadley v. Baxendale. Even without that principle, under a straightforward application of the Coase Theorem, $C$, as the highest value user, would end up witl the truck whether or not $B$ communicates his valuation of the truck at the time the contract is made. If $A$ is liable for $B$ 's reasonably foreseeable damages-and not just for $B$ 's probable damages, as under Hadley $-A$ will negotiate witl $B$ prior to breach, and either $A$ or $B$ will sell tlie truck to $C$. An example will illustrate why this is so.

Assume the following facts to flesli out Danzig's hypotlietical: $A$ and $B$ make their contract on January 2 for dehvery on February 1. The price to $B$ is $\$ 25,000$. He plans to use the truck in a profit-making activity as soon as it is dehvered. If delivery is not made, it will take a month to fill an order for a comparable truck elsewliere. During that month, $B$ will either have to use an older truck tliat costs more to operate or is not well suited for his needs, or be required to forgo the profit-making activity. Therefore, $B$ values the truck at $\$ 28,000$. (The difference between $\$ 28,000$ and $\$ 25,000$ in effect represents $B$ 's consequential damages on breach.) For comparable reasons, $C$ values the truck at $\$ 30,000$ and is willing to pay that amount. At the time he made the contract, $B$ did not communicate to $A$ that he valued the truck at $\$ 28,000$, but it was reasonably foreseeable (even if not probable) that $B$ valued the truck at inore than $\$ 25,000$. The principle of Hadley v. Baxendale is not followed.

Suppose first that $C$ knows that $B$ lias a contract to buy tlie truck for $\$ 25,000$. $C$ would then simply buy the contract from $B$ for some amount between $\$ 3000$ ( $B$ 's surplus value) and $\$ 5000$ ( $C$ 's surplus value) and would end up with the truck.

Suppose next tliat $C$ doesn't know about $B$ 's contract, and approaches $A$ directly. In the absence of the principle of Hadley $v$. Baxendale, $A$ will be hable for $B$ 's reasonably foreseeable damages if he sells the truck to $C$ without $B$ 's consent. To avoid that hability, after $C$ approaches $A, A$ would either pay $B$ some amount between $\$ 3000$ and $\$ 5000$ to rescind the contract or would sell $B$ or $C$ information concerning the other's identity. $C$ again would end up witli the truck. ${ }^{61}$

60. Danzig, supra note 3, at 282. Danzig himself is somewhat ambivalent about the force of this illustration as a rationale for the principle of Hadley v. Baxendale:

[I]f the rule were truly finely geared to optimizing the allocation of resources, it would place its emphasis on the damage known to the seller at the time of breach, rather than at the time of contract, at least where the breach was voluntary. ... Would it be desirable to move the focus of the rule to this point? On this question, some empirical evidence would be desirable.

Id. at 283.

61. The same results hold if $B$ values the truck more than $C$. Suppose that $B$ values the truck 
Rejection of the principle of Hadley v. Baxendale also would not increase the transaction costs of moving goods to the highest value user. Only three types of transaction costs are relevant in this situation: the cost of contracting $(K)$, the cost of disputing $(D)$, and the cost of communicating inforination $(I) .{ }^{62}$ Assume the following facts: the cost of contracting does not vary significantly as between any two parties. The original cost of contracting between $A$ and $B$ is a sunk cost. $B$ did not communicate the value he placed on the truck when the contract was nade. Given what $A$ knew, it was reasonably foreseeable, although not probable, that $B$ would incur consequential damages if $A$ breached. The principle of Hadley v. Baxendale is not followed.

Case 1. Suppose first that when $C$ determines to purchase the truck, she knows about $B$ 's contract with $A$. If $A$ honors his contract with $B$, the transaction cost of getting the truck to $C$ is $K$ (the cost of contracting between $B$ and $C$ ). If $A$ breaches his contract with $B$ and sells the truck to $C$, the transaction costs of getting the truck to $C$ are $K+D$ (the cost of contracting between $A$ and $C$ plus the cost of disputing between $A$ and $B)$.

Obviously, in Case 1 the transaction costs of getting the truck to $C$ are lower if $A$ honors his contract with $B$ (transaction cost $=K$ ) than if he breaches that contract (transaction costs $=K+D$ ).

Case 2. Same as Case 1, except that $C$ does not know about $B$ 's contract with $A$. If $A$ breaches the contract with $B$ and sells the truck to $C$, the transaction costs of getting the truck to $C$ are $K+D$. (See Case 1.) If A simply honors his contract with $B$, the transaction cost of getting the truck to $C$ is only $K$. (See Case 1.) If $A$ wants to get some advantage from $C$ 's offcr, without breaching the contract with $B, A$ will either contract with $B$ to rescind or sell $B$ or $C$ infornation concerning the other's identity. Because the cost of disputing is almost certain to exceed either the cost of contracting to rescimd or the cost of comnuunicating inforination, the transaction costs in Case 2 of getting the truck to

at $\$ 30,000$, and $C$ values the truck at $\$ 28,000$ and offers to pay $A$ that amount. If $A$ simply honors the contract with $B, B$ would end up with the truck. If $A$ believes that $C$ 's offer exceeds the value that $B$ places on the truck, $A$ can offer to rescind the contract with $B$ in exchange for a payment to $B$ of some amount between $\$ 1$ and $\$ 3000$ (the difference between $C$ 's offer and the price under the contract with $B$ ). If $B$ is rational, he would accept a payment in this range if it exceeded the difference between the contract price of the truck and the value he places on the truck. On the facts supposed, $B$ would not accept the offer and would end up with the truck. Again, under either scenario the truck ends up in the hands of the highest value user even if the principle of Hadley $v$. Baxendale is not in effect and $B$ did not communicate his valuation of the truck when the contract was made.

62. The cost of delivery is not relevant because if $C$ values the truck more than $B, B$ will assign his rights under the contract to $C$ before delivery is made. The cost of delay is also not relevant. If $C$ approaches $B$ before the delivery date under the contract with $B$, then $A$ can deliver the truck to $C$ rather than to $B$ on the delivery date. If $C$ approaches $A$ after the delivery date, it will be too late for $A$ to deliver the truck to $C$ in any event. 
$C$ are almost certain to be less if $A$ honors the contract than if he breaches the contract.

The principle of Hadley v. Baxendale therefore cannot be explained by the theory of efficient breach. Indeed, the principle of Hadley $v$. Baxendale is inconsistent with the theory of efficient breach. Under that theory, the decision to perforin or to breach a contract should depend on the costs and benefits of breach to both parties at the time the decision to breach is made. Under the principle of Hadley v. Baxendale, however, the seller, in determining whether to breach, can disregard all reasonably foreseeable costs except those he has reason to know are probable at the time the contract is made. ${ }^{63}$ Therefore, the theory of efficient breach suggests that the principle of Hadley $v$. Baxendale promotes inefficiency, because the principle allows the seller, in deciding whether to breach, to disregard reasonably foreseeable and even known costs that will result from breach, as long as those costs were not probable or were probable at the time of breach but not at the time of contract formation.

\section{The Information-Forcing Argument}

\section{The General Argument}

The manner in which the principle of Hadley v. Baxendale focuses on what the seller knows at the time the contract is made, rather than on what he knows at the time of breach, suggests still another, nnore plausible efficiency argument for the principle. A seller norinally has a choice whether to enter into a contract and whether and how to take account of inforination concerning the damages that might result froin its breach. For example, if a seller knows that a buyer will probably imcur consequential damages, the seller might raise its price, take greater-than-normal precaution to ensure its own perfornance, or both. Efficiency, it may then be argued, requires the buyer to communicate to the seller inforination on those special circumstances, so that the seller can inake any desired adjustinents in his behavior. ${ }^{64}$ The principle of Hadley $v$.

63. There is a limited exception. Where a carrier fails to make delivery after a shipment has reached its destination, and nothing except delivery remains to be done, the carrier is responsible for the consequential damages it was then informed would likely result from breacl. In Turner's Farms, Inc. v. Maine Central Railroad, 486 F. Supp. 694, 699-700 (D. Me. 1980), the court stated that this special rule is a "well-established common law exception to the rule of Hadley $v$. Baxendale" The court continued: "The rationale for the special rule is that after a shipment las reaclied its destination point the risks of actual shipment are complete, and when notice of special circumstances is given at this point, the carrier is capable of taking the necessary precautions to avoid negligent delay of delivery." Id. at 700 .

64. See, e.g., Easterbrook \& Fiscliel, supra note 16, at 113 n.45 ("The foreseeability doctrine of Hadley y. Baxendale demes recovery for nonforeseeable losses, which gives plaintiffs an incentive to disclose any nnusual conditions and risks at the time of the transaction. Disclosure, im turn, allows the other party to take extra precautions or to cliarge appropriate compensation for bearing increased risk.") (citation omitted). 
Baxendale provides an incentive to the buyer to make that communication.

Indeed, a form of this argument was adopted by the court in Hadley v. Baxendale itself. " $[\mathrm{H}] \mathrm{ad}$ the special circumstances been known," the court said, "the parties might have specially provided for the breach of contract by special terms as to the damages in that case; and of this advantage it would be very unjust to deprive them." 65 This argument has the apparent incidental advantage of justifying the divergence between the principle of Hadley v. Baxendale and the principles of tort damages, since, it might appear, a tortious wrongdoer does not have the same opportunity as a contracting party to price and plan for unusual damages. ${ }^{66}$ Because the primciple of Hadley v. Baxendale is a default rule, an assessment of this argument must turn partly on a comparison of the benefits and costs of the principle of Hadley v. Baxendale taken in itself and partly on the relative benefits and costs of Hadley v. Baxendale and the coinpeting regime of proximate cause, contractual allocations of loss, and fair disclosure.

The balance of Section III.C will consist of an analysis of the principle of Hadley v. Baxendale as an inforination-forcing device. For purposes of this analysis, I will distinguish between the benefits of information-forcing in contracts for relatively differentiated commodities (see Section III.C.2) and contracts for relatively homogeneous comınodities (see Section III.C.3). I will also distimguish between the conceivable benefits of the principle in theory (see Section III.C.4) and the costs mvolved in achieving those conceivable benefits in practice (see Section III.C.5). After that, I will weigh the likely net benefits of the principle agamst its costs (see Section III.C.6).

\section{Relatively Differentiated Commodities}

Differentiated commodities are often tailored to the buyer's special needs. As a result, the principle of Hadley v. Baxendale typically will not, or at least need not, come into play in the case of differentiated commodities because the precontract parley-specifications, quotations, preliminary discussions, and negotiations-will normally put the seller on notice of the buyer's special circumstances.

Sellers of differentiated commodities are likely to know or have reason to know the buyer's special circumstances even if the commodity is

65. Hadley v. Baxendale, 156 Eng. Rep. 145, 151 (Ex. Ch. 1854). For similar expressions, see Koufos v. C. Czarnikow Ltd. [The Heron II], [1969] 1 App. Cas. 350, 386 (opinion of Lord Reid), 413 (opinion of Lord Pearce), 422 (opimion of Lord Upjohn) (1967) (appeal taken from Eng.).

66. This is often called the "information-forcing" argument. I use that nomenclature in this Article, although it is somewhat inaccurate because, while the principle of Hadley v. Baxendale might provide an imcentive to a buyer to communicate information, it does not force a buyer to communicate information. 
not specifically tailored to the buyer's special needs. For example, in Victoria Laundry (Windsor) Ltd. v. Newman Industries Ltd. the court held that Newman, the seller, was hable for the lost laundry profits of Victoria, the buyer. During the negotiations Victoria had expressed its mtention to put the boiler to use in the shortest possible time. Therefore, the court concluded, Newman had reason to know that Victoria would forgo laundry profits if dehvery was late:

The defendants were an engineering company supplying a boiler to a laundry. We reject the submission for the defendants that an engineering company knows no more than the plain man about boilers or the purposes to which they are commonly put by different classes of purchasers, including laundries. ... The obvious use of a boiler, in such a business, is surely to boil water for the purpose of washing or dyeing ... for purposes of business advantage, in which tern we, for the purposes of the rest of this judginent, include inaintenance or increase of profit, or reduction of loss .... No commercial concern commonly purchases for the purposes of its business a very large and expensive structure like this-a boiler 19 feet high and costing over $£ 2,000$ - with any other motive, and no suppher, let alone an engineering company, which has promised delivery of such an article by a particnlar date, with knowledge that it was to be put into use immediately on delivery, can reasonably contend that it could not foresee that loss of business (in the sense indicated above) would be liable to result to the purchaser from a long delay in the detivery thereof. ${ }^{67}$

It is true that a seller of a differentiated commodity, although knowing that the buyer will incur consequential damages in the event of breach, might not know the probable amount of such damages. Indeed, the Victoria Laundry court took just this view, ${ }^{68}$ saying, in effect, that the seller was on notice that Victoria would lose dyemg profits but was not on notice that the lost profits would be supranormal. ${ }^{69}$ This branch of the opimion, however, is difficult to justify under the efficiency arguments for the primciple of Hadley v. Baxendale. If the seller had reason to know that Victoria would probably lose dyeing profits if the boiler was not dehivered on time, the seller also had reason to know that Victoria's actual lost dyeing profits might be normal, infranornal, or supranormal. As a inatter of efficiency, that is all the seller needed to know, unless the dainages were so far above normal that the ex ante probability of their occurrence was not significant. ${ }^{70}$ (Even in that case, however, the buyer

67. Victoria Laundry (Windsor) Ltd. v. Newman Indus. Ltd., [1949] 2 K.B. 528, 540-41 (Eng. C.A.).

68. Id. at $542-43$.

69. Id. at 543; accord Guetzkow Bros. v. Andrews, 66 N.W. 119, 122 (Wis. 1896) (holding that if seller has reason to know buyer is purchasing for resale, seller is liable for buyer's lost reasonable profits, but not for lost extraordinary profits).

70. Cf. Joskow, supra note 17 , at 160-61 ("[A]symmetric treatment of differing consequences 
should be entitled to damages up to the level where the probability of their occurrence lacked significance, rather than simply "normal" damages, as were awarded in Victoria Laundry.)

In the later case of H. Parsons (Livestock) Ltd. v. Uttley Ingham \& Co., Lord Justice Orr adopted the position that the seller's " 'assumed contemplation should be limited to the type of damage that occurs but ... he is hable if the quantum is greater than he may be presumed to anticipate." "71 Posner, who is generally friendly to the principle of Hadley v. Baxendale, ${ }^{72}$ takes the same view and offers an important efficiency reason in its support:

The rule of Hadley v. Baxendale is not applied, it should be noted, where what is unforeseeable is the other party's lost profit. Suppose I offer you $\$ 140,000$ for a liouse tliat has a market value of $\$ 150,000$, you accept the offer but later breacli, and I sue you for $\$ 10,000$, my lost profit. You would not be permitted to defend on the ground that you had no reason to think the transaction was such a profitable one for me. Any otler rule would make it difficult for a good bargainer to collect damages unless before the contract was signed he had made disclosures that would reduce the advantage of being a good bargainer-disclosures that would prevent the buyer from appropriating the gaius from lis efforts to identify a resource that was undervalued in its present use. ${ }^{73}$

from similar events only appears to make sense if we expand our notion of possible contingencies to include elements identified by both event and consequence, and assume that, given a particular type of occurrence, the size of the consequence and the probability of the consequence occurring are negatively correlated.").

71. H. Parsons (Livestock) Ltd. v. Uttley Ingham \& Co., [19781 1 Q.B. 791, 805 (Eng. C.A. 1977) (opinion of Orr, L.J.) (quoting lower court opinion of Swanwick, J.).

An analogy is Seabrook Shipyard v. Eaton, 428 S.W.2d 843 (Tcx. Civ. App. 1968), writ ref. n.r.e. (Tex. Oct. 2, 1968). $S$ had rented to $B$ a very large storage stall for $B$ 's boat, which $B$ wanted in order to protect the boat from the weather. The boat stood six feet above the water, and the stall was forty feet high. $S$ agreed not to move the boat to a smaller stall without obtaining $B$ 's permission. In breach of its contract, without obtaining $B$ 's permission $S$ moved the boat to a stall that was only twenty-one feet high. A hurricane that carried a fifteen-foot tide and heavy wave action damaged $B$ 's boat. If the boat had not been moved to the ncw stall, it would not have been damaged. The vicinity of the shipyard had been struck by only six or eight hurricanes in twenty years, and the probability of a hurricane with the force involved was very low. The court held that $S$ was nevertheless hable for the damage to $B$ 's boat.

Similarly, upon the breach of a burglar-alarm or a security-guard contract, the very low likelihood of a crime at the given place and time is irrelevant. See Sandvik, Inc. v. Statewide Sec. Sys., 469 A.2d 955, 958 (N.J. Super. Ct. App. Div. 1983) (holding seeurity guard service liable for total amount of stolen inventory when employee was bribed to leave his post and purpose of hiring guard was to help abohish inventory loss); Ligon v. Chas. P. Davis Hardware, Inc., 492 S.W.2d 374, 376 (Tex. Civ. App. 1973) (holding installers of alarm system liable for loss suffered through theft when alarm failed to sound upon store's being broken into on "the view that the loss suffered was one which was fairly and reasonably within the contemplation of the parties at the time they entered into the service agreement").

72. See supra text accompanying notes 54-57.

73. POSNER, supra note 56 , at 115 . 


\section{Relatively Homogeneous Commodities}

Now suppose a commodity is relatively homogeneous. Such commodities are characteristically sold without the kind of precontract parley that in the case of differentiated commodities typically puts the seller on notice of the buyer's special circumstances. It is therefore true that in the case of relatively homogeneous commodities, the seller normally would not have reason to foresee that breach will likely cause consequential damages to any individual buyer, unless the buyer commumcates to the seller information concerning his special circumstances. A rule of law that provides an incentive to the buyer to communicate such information therefore seems to confer a substantial efficiency gain by allowing a seller of homogeneous commodities to set an appropriate price, and take appropriate precautions, in transactions that might involve consequential dainages.

If, however, we focus on statistics and probabilities rather than on individual cases, a much different picture emerges. The real interest of a seller is not whether a buyer will have consequential dainages, but whether the buyer will have supranormal damages. Sellers of relatively homogeneous commodities often sell a great many umits of the commodity and develop an extensive claims experience, which presumably will be reflected in a probability distribution. Although such a seller might not know whether any individual buyer will likely incur supranormal damages on breach, it will often know that a given percentage of its buyers will almost certainly incur supranormal damages on breach. ${ }^{74}$ Accordingly, a high-volume seller of hoinogeneous commodities can reliably price and plan for supranormal damages, even im the absence of information resultimg from the incentives provided by the principle of Hadley $v$. Baxendale, by setting an equilibrium price ${ }^{75}$ and level of precaution that takes into account, on a weighted basis, all losses that are a reasonably foreseeable result of the breach.

\section{The Insurance Conception and the Stratification of Prices and Precaution}

There are, nevertheless, conceivable efficiency gains that might result from the primciple of Hadley v. Baxendale that cannot be achieved by setting a single equilibrium price and level of precaution. A contractual obligation is sometimies conceived as a promise either "to perform or to pay damages" ${ }^{36}$-or, to put it differently, as a frontline promise to

74. More accurately, the seller will know that a certain percentage of buyers will suffer damages that are just above the median, a somewhat smaller percentage will suffer damages that are further above the median, and so forth.

75. See Danzig, supra note 3 , at 281.

76. Globe Ref. Co. v. Landa Cotton Oil Co., 190 U.S. 540, 543 (1903). 
perform and a backstop promise to pay compensation in the event of nonperformance. This backstop promise, in turn, might be viewed as a special kind of insurance by the promisor that in the event of nonperformance the promisee will be made as well-off as if performance had occurred. In the case of conventional insurance, efficiency normally requires an insurer to stratify the total population of insureds into subgroups based on risk. The meinbers of each subgroup then pay different premiums based on the risk each presents, rather than uniform premiuins that aggregate the risks presented by more and less risky subgroups. As a result, less risky insureds do not subsidize more risky insureds.

Similarly, if in a contract for the sale of a commodity various buyers present significantly different hability risks, efficiency may require the seller to stratify buyers into subgroups based on those risks. The members of each subgroup would then pay different prices based on the liability risk each presents, rather than uniform prices that aggregate the highand low-hability buyers. As a result, buyers who will incur normal damages on breach would not subsidize buyers who will incur supranormal damages. By the same token, efficiency may require sellers to stratify precautions, taking more precaution in contracts with high-hability buyers and less precaution in contracts with low-hability buyers. The principle of Hadley v. Baxendale conceivably assures that sellers will have an opportumity to efficiently stratify prices and precautions for buyers who present varying risks of hability. These conceivable efficiency gains avoid the objection that a high-volume seller of homogeneous goods can reliably price and plan on the basis of its overall claims experience even without nuformation generated by the incentive of Hadley v. Baxendale.

\section{Costs That Must Be Incurred to Communicate and Utilize the Relevant Information}

As shown in the previous section, in theory an argument can be made that the primciple of Hadley v. Baxendale is efficiency enhancing on the basis of the stratification of pricing and precaution. In practice, however, the extent to which the conceivable efficiency gains based on such stratification are likely to be achieved is drastically reduced, even in the first instance, by the costs of communicating and utilizing the relevant nuformation.

\section{a. Costs of Processing Information}

To begin with, a seller who proposes to make use of the information about consequential damages that the Hadley v. Baxendale rule theoretically produces must incur the costs of processing that information. For example, the seller must train his employees to recognize relevant information, create and maintain protocols for utilizing such information, and 
expend employee time in applying the protocols. Often, these costs will exceed the benefits of using such information.

To illustrate, assume that Ajax, a seller, makes 100,000 contracts a year and breaches $1 \%$ of those contracts in a random fashion. Direct damages for breach by Ajax average $\$ 50$, and consequential damages, for those buyers who incur them, average $\$ 500$. It is probable that $5 \%$ of buyers will incur consequential damages. Call these buyers " $\mathrm{CD}$ buyers," and call the contracts they enter into "CD contracts." The annual amortized cost to Ajax for training employees and creating and inaintaining the required protocols is $\$ 15,000$. The cost of processing the relevant information in any given case is $\$ 6$ per contract, or $\$ 30,000$ for the 5,000 CD contracts. On these facts, Ajax will not process the information because the total cost of utilizing the information, $\$ 45,000$, will exceed the total consequential damages, $\$ 25,000$ ( $\$ 500$ times $1 \%$ of the $5000 \mathrm{CD}$ contracts). The Hadley principle will not, as a practical inatter, affect Ajax's behavior.

\section{b. Costs of Stratifying Precautions}

Just as the cost of processimg the infornation that is relevant under the principle of Hadley v. Baxendale can exceed the benefits to the seller, so can the cost of stratifying precautions. It soinetimes seems to be an implicit assumption of contract analysis that the rate of inaterial breach ${ }^{77}$ is relatively high. In fact, however, observation suggests that this rate tends to be very low. Contracting parties, particularly buyers, place an enormous premium on rehiable planning, and sellers who develop a reputation for a relatively high rate of breach will not stay long in business.

Although the concept of stratifying precaution has becoine a inajor justification of the principle of Hadley v. Baxendale, ${ }^{78}$ in practice such stratification is extremely unlikely to occur. Sellers of homogeneous commodities typically sell those commodities in high volune, and for a high-volume seller with a low rate of breach, the costs of stratifying precaution will typically exceed the benefits even when the seller knows which contracts carry a risk of higher-than-average hability. A high-volume seller with a low rate of breach will norinally find it cheaper not to stratify precaution, and simply to pay high dainages in some cases, than to reduce its damage exposure by paying the costs of segregatimg transactions along a number of different tracks, with different precautions for each track. So, for example, casual einpirical research indicates that carriers such as airlines, express-mail handlers, and household inovers nor-

77. Material breach includes nonperformance or material delay, not minor or trivial breaches that are to be expected in any complex performance and that are customarily made up through a monetary allowance by the seller.

78. See, e.g., Ayres \& Gertner, supra note 14, at 101-04. 
mally take no greater precautions in transporting goods that they know have a declared high value, and for whose loss they have agreed to pay supranormal damages, than in transporting other goods. ${ }^{79}$

More generally, where the rate of inaterial breach is low, it will often be inefficient for sellers to incur costs that are relevant only to breach. Since observation suggests that the rate of breach is usually very low, it follows that for many or inost sellers, particularly high-volume sellers of homogeneous goods, the costs both of processing information that is relevant under the primciple of Hadley $v$. Baxendale and of stratifying precautions will exceed the expected value of utilizing such information. Therefore, in the case of high-volume sellers of hornogeneous goods, and indeed inany or most other sellers, information that is generated through the incentive of that principle will not be utilized-just as the information given to Pickford's clerk in Hadley v. Baxendale was not utilized. These efficiency reasons for not stratifying precaution explain, at least in part, Cardozo's observation, in the context of telegraph coinpamies, that:

[t]he truth seems to be that neither the clerk who receives the message over the counter nor the operator who transmits it nor any other employee gives or is expected to give any thought to the sense of what he is receiving or transmitting. This imparts to the whole doctrine as to the need for notice [under Hadley v. Baxendale] an air of unreality. ${ }^{80}$

\section{c. Costs of Communicating Information}

The potential gains froin information generated through the incentive of Hadley v. Baxendale are further reduced in practice by the buyer's costs of communicating the relevant information. Assuining that a buyer is aware of the Hadley principle, he inust, at a mininum, incur the costs of assembling the information (itself no sinall task, because exactly what information will be relevant under the primciple of Hadley v. Baxendale is often not self-evident) and transinitting that information. These costs alone can exceed the expected value of cornınunication. In the Ajax illustration, for example, the expected value to a CD buyer of communicating the relevant information will be $\$ 5$ ( $\$ 500$ in consequential damages if breach occurs, multiphed by a $1 \%$ probability of breach). If the cost of assembling and transmitting the relevant information is $\$ 6$, the information will not be commumicated. More generally, for buyers as well as for sellers, if the seller's rate of breach is low, as it usually is, it

79. Telephone Interviews by Daniel A. Saunders with: Jim Hanon, Director of Underwriting for Umited Van Lines; Trudy Atkinson, Customer Service Agent for Federal Express; Tina McGuire of Emery Air Freight; Alice Rogers of American Airlines; and representatives of Airborne, Pan Am, United, and TWA.

80. Kerr S.S. Co. v. Radio Corp. of Am., 157 N.E. 140, 142 (N.Y.), cert. denied, 275 U.S. 557 (1927). 
will often be mefficient to incur costs that are relevant only on material breach.

In many cases the communication of information concerning consequential damages would involve a cost much more substantial than the cost of assembly and transmission. Information that is valuable to a buyer might lose much of that value when transmitted. For example, suppose the buyer is a middleman expecting to consummate a resale at a very advantageous price. If the market is not perfectly competitive, a buyer who communicates information concerning the special value to him of the seller's commodity is likely to find that the seller will raise his price to capture sonie of the added joint surplus of which he is now made aware. Indeed, in sone cases a seller who receives such information might beheve it would be better off by not selling to the buyer but instead locating the buyer's customer and selling to that customer directly. ${ }^{81}$ Even if the market is perfectly conpetitive, if the buyer is a manufacturer it might be unable to transmit information about its planned use of a commodity without also disclosing proprietary information concerning its nianufacturing process. These kinds of costs to the buyer for commumicating information that is relevant under the primciple of Hadley $v$. Baxendale will often be so substantial as to swamp the expected value of the communication.

Furthermore, if a buyer's normal expectations are taken into account, it is unreasonable to place the costs of communicating information on the buyer. The imsurance conception of contract does not accurately represent the psychology of contracting parties. Buyers normally do not bargam for an undertaking by the seller to either perform or be liable to pay conipensation, as the seller chooses. Buyers bargain for performance. ${ }^{82}$ A reasonable buyer, having bargamed for and obtained a commitment to perform, is likely to beheve that there is no reason to undertake the costs required to elaborate to the seller the reasonably foreseeable results of breach. Finally, regardless of cost, a buyer cannot transmit information concerning its consequential daunages when the relevant information does not materialize until after the contract has been made.

In practice, therefore, the benefits of the principle of Hadley $v$. Baxendale appear to be extremely limited. In theory, the principle provides an incentive to buyers to reveal information concerning their special circumstances at the time a contract is made, and thereby allows a seller to either determine an equilibrium price and level of precaution

81. See Janet T. Landa, Hadley v. Baxendale and the Expansion of the Middleman Economy, 16 J. LEGAL STUD. 455, 463-65, 467 (1987).

82. Contracting parties of course realize that breach might occur but that realization is not inconsistent with an expectation that performancc almost certainly will occur. 
that appropriately reflects its overall hability risk or to stratify precautions according to varying hability risks. As a practical matter, however, this benefit is seldom likely to be attained. Sellers of relatively differentiated commodities will normally learn of any special circumstances as a result of precontract parley. High-volume sellers of homogeneous commodities can often determine the equilibrium level of pricing and precaution simply by the use of statistical analysis. Most high-voluine sellers of hoinogeneous commodities will not utilize information concerning special circumstances to stratify precaution because the cost of processing the information, stratifymg precaution, or both will exceed the expected value of the stratification.

Similarly, many or most buyers will not coinmumicate information concerning their special circumstances. It is reasonable for laymen not to know the intricacies of damage law. Buyers who reasonably do not know the primciple of Hadley v. Baxendale will not commumicate information about their reasonably foreseeable damages because they will deem it unreasonable and unnecessary to incur the costs of doing so. Buyers who know the primciple may also reasonably fail to cominunicate such information, because, for example, the cost of setting up systems and commumicating information will exceed the expected value of coinmumication; the buyer knows the seller will not use the information; commumication of information will cause the loss of soine or all of the value of the information to the buyer; or the information does not arise until after the contract has been made.

\section{The Secondary Costs of the Principle of Hadley v. Baxendale}

Assume that despite the substantial costs of communicating and utilizing information relevant under the incentive of the principle of Hadley v. Baxendale, there reinain limited first-instance net benefits. Those net benefits must now be weighed both against the costs of the primciple other than the first-instance costs of commumicating and utilizing the relevant information, and against the benefits and costs of an alternative regime of proximate cause, contractual allocations of loss, and fair disclosure. I shall consider the costs of the principle of Hadley $v$. Baxendale in this Section and the relative benefits and costs of the alternative regime in Part IV.

One inajor cost of the Hadley primciple is that it provides inefficient incentives for the rate of performance. The principle allows the seller, in determining whether to breach, to disregard reasonably foreseeable costs that are not probable costs or that become known before breach but after the contract is made. To put this differently, the principle of Hadley $v$. Baxendale conflicts with the theory of efficient breach. Under that theory, if the reasonably foreseeable losses that the buyer will incur as a 
result of breach exceed the gains to the seller, the seller should perform. However, under the principle of Hadley v. Baxendale as traditionally formulated and applied, the seller need not perform, because he will not be liable for those losses unless they are both reasonably foreseeable and probable not only at the time of breach, but at the time the contract is made. In effect, the principle of Hadley v. Baxendale gives greater weight to the efficient rate of precaution than to the efficient rate of perfornance. This strikes the wrong balance. Because of the number of contingencies involved in determining the appropriate rate of precaution, and the complexity and uncertainty of each contingency, precise calculations of the rate of precaution at various hability levels are likely to be both very costly and very unrewarding, and therefore will frequently be forgone. Even if such calcnlations are made, they will often show that stratifying precaution will not be worth its costs. Accordingly, sellers who are concerned with the prospect of supranormal dainages are inuch more likely to deal with that prospect by taking an average ainount of precaution and allocating hability by contract, rather than by stratifying the level of precaution. In the context of evaluating the principle of Hadley v. Baxendale, therefore, the loss of efficiency that the primciple causes in the rate of perforinance outweighs the gain of efficiency that the principle causes in the rate of precaution.

The principle of Hadley v. Baxendale entails less obvious costs as well. First, it provides inefficient incentives for investing in infornation. Under the principle, buyers who invest in information are often put to the choice of commumicating the inforination to the seller, and thereby incurring a loss of all or part of that value, or forgoing dainages that are the reasonably foreseeable consequences of the seller's breach. Second, in cases where the seller will not utilize information concerning consequential damages because the expected costs of doing so excecd the expected value, the principle requires buyers who want to recover consequential dainages to incur costs for commumicating information that will have no effect on the seller's behavior. Finally, the principle of Hadley $v$. Baxendale defeats reasonable expectations because a seller's commitment to perforin would often be understood by a buyer as a commitunent to shoulder reasonably foreseeable dainages caused by the seller's breach.

Although the relative costs and benefits of the principle of Hadley $v$. Baxendale are impossible to quantify with a high degree of accuracy, it is a fair conclusion that the costs significantly exceed the benefits. ${ }^{83}$ In con-

83. A comparable conclusion is reached in Jason S. Johnston, Strategic Bargaining and the Economic Theory of Contract Default Rules, 100 YALE L.J. 615 (1990), through the application of game-theoretic analysis, although the robustness of the analysis is limited by its dependence on very restrictive assumptions concerning the nature and operation of the markets in which bargaining will occur and the characteristics and psychology of bargaining parties. 
trast, as I will show in Part IV, under the alternative regime of proximate cause, contractual allocations of loss, and fair disclosure, the benefits would be very high and the costs very low.

\section{IV}

\section{A Better legal Regime: Proximate Cause, CONTRACTUAL Allocations OF LOSS, AND FAIr Disclosure}

In Part II, I showed that the principle of Hadley v. Baxendale diverges froin both the general principles of expectation damages and the principles of damages outside contract law. In Part III, I showed that this divergence was not justified by the modern arguments for the principle. I will now explore the legal regine that should be adopted in place of the principle of Hadley v. Baxendale. This regime has three eleinents: the principle of proximate cause, the use of contract to allocate losses, and a requirement of fair disclosure.

\section{A. The Elements of the Alternative Regime}

\section{Proximate Cause}

Under general principles of law, hability is nornally limited by the principle of proximate cause. This principle should apply in contract law as well. Although there are coinpeting conceptions of the principle of proximate cause, ${ }^{84}$ the ascendant conception is that, with the possible exception of personal injury that results froin a tortious impact, ${ }^{85}$ proxiinate cause is based on the scope of the risks that were foreseeable at the

84. See, e.g., 4 Fowler V. Harper ET AL., THE LAW of TORTS $\$ \S 20.5-.6$, at 133-85 (2d ed. 1986); W. Page Keeton et al., Prosser and Keeton on the LAW of TORTS $§ 43$, at 281-82 (5th ed. 1984).

85. When injuries follow from a tortious impact upon the person as a result of the person's preexisting physical condition, the wrongdoer is liable for all resultant larm, whether or not reasonably foreseeable, 4 HARPER ET AL., supra note 84, § 20.5, at 162-69; KEETON ET AL., supra note $84, \S 43$, at $291-93$, and liability is likely to be even furtler extended in the case of intentional torts. Harper states that a wrongdoer is also liable for all resultant harm, whether or not foreseeable, in cases involving damage to property "where because the stage is set for it the extent of the injury passes all bounds of reasonable anticipation," 4 HARPER ET AL., supra note $84, \S 20.5$, at 144, but cites im support only In re Polemis, [1921] 3 K.B. 560 (Eng. C.A.), whose present authority is doubtful, see supra text accompanying notes 44-46.

The rule concerning liability for personal injuries is not necessarily inconsistent with the general principle of reasonable foreseeability. The general principle is often fornulated to mean that the wrongdoer must only have had reason to foresee an injury of the kind that occurred. Much therefore depends on how broadly the kind of injury is defined. If the kind of injury required to be foreseen is simply "an injury to the person," then the rule concerning personal injuries would be only a special case of the general principle. Lord Scarman took just this position in $H$. Parsons (Livestock) Ltd. v. Uttley Ingliam \& Co., Ltd., [1978] 1 Q.B. 791, 813 (Eng. C.A. 1977) (opinion of Scarnan, L.J.). 
time of the wrong. ${ }^{86}$ Therefore, substituting the principle of proximate cause for the principle of Hadley v. Baxendale would not result in liability for all damages that are factually caused by a breach.

As in other areas of law, the standard of foreseeability required under a regime of proximate cause in contract should depend not on how the suit is classified, but rather on the nature of the interest invaded and the wrong involved. In torts, for example, the standard of foreseeability varies according to whether a case involves personal injuries resulting froin negligence, economic loss resulting froin neghigence, or damage that is intentionally caused. The standard of foreseeability required in contract should depend on coinparable eleinents-on whether, for example, the interest involved is injury to the person, physical injury to property, lost profits, out-of-pocket costs, or forgone opportunities, and whether the breach was inadvertent or opportunistic. The baseline standard when lost profits or forgone opportunities are involved should be what $I$ have called reasonable foreseeability: whether the prospect that the damage would occur was more than inarginal, or not insignificant. That standard should be applied to the amount of damages as well as to their nature.

A somewhit comparable approach was suggested by Lord Denning in H. Parsons (Livestock) Ltd. v. Uttley Ingham \& Co ${ }^{87}$ In cases mvolving physical mjury to person or property, Lord Denning said, the defaulting party should be liable, in both tort and contract, "for any loss . . . which [reasonably could have been] foreseen at the time of the breach ... even if it was only a slight possibility." 88 In cases involving "economic loss" or loss of profit, the defaulting party should be liable, in both tort and contract, for consequences that "are such as, at the timie of the contract, he ought reasonably to have contemplated as a serious possibility or real danger." 89

Finally, reasonable foreseeability should be determined as of the time of the breach, so that in deciding whether to breach the seller must sweep into its calculus all the costs that it should reasonably foresee will be incurred by the buyer as a result of breach. Application of the foreseeability standard at the time of breach, rather than at the time the contract is made, gives precedence to the rate of efficient breacl over the rate of precaution. However, it is mescapable in this context that one of these rates must dominate the other. It is preferable to give precedence to efficient breach, because $\mathrm{m}$ practice the rate of precaution is likely to depend

86. 4 HARPER ET AL., supra note $84, \S 20.5$, at 136-37; KeETON ET AL., supra note $84, \S 43$, at 297-300.

87. [1978] 1 Q.B. 791, 798-804 (opinion of Lord Denning, M.R.).

88. Id. at $802-03$.

89. Id. 
on contractual allocations of loss and precontract judgments based on probability, rather than on information commumcated at the time of contracting. ${ }^{90}$ Moreover, contracting parties should not be encouraged to make decisions on breach that fail to sweep into their calculus all costs that are reasonably foreseeable at the time the decision is made.

\section{Contractual Allocations of Loss}

As applied to contracts, the principle of proximate cause, like the principle of Hadley v. Baxendale, would be a default rule. In most cases a buyer's damages would be limited by contractual provisions, not by the principle of proximate cause. Even under the regime of Hadley $v$. Baxendale, sellers commonly limit their hability, and stratify prices, not through rehance on that principle but through contractual provisions that allocate losses. Such provisions may, for example, preclude consequential damages by putting a dollar or formula limit on liability, by offering various hability limits in exchange for various prices, or by substituting for dollar hability some other obligation such as replacement or repair. I will refer to such provisions as "contractual allocations of loss."

It is not hard to see why sellers commonly prefer to hmit their hability through contractual allocations of loss rather than by relying on the principle of Hadley v. Baxendale. The most plausible efficiency justification for the principle of Hadley v. Baxendale is that it provides an incentive to the buyer to commumicate information that will allow the seller to price and plan reliably and, if he chooses, to stratify precautions according to the risk of liability. From a seller's perspective, therefore, at best that primciple either will provide an incentive to the buyer to communicate information about consequential damages or will protect the seller against hability if the relevant information is not communicated.

Typically, however, a seller's imterest is not whether a buyer will have consequential damages but whether a buyer will have supranormal damages. Direct dainages-whose recovery is not affected by the principle of Hadley v. Baxendale - could be supranormal while consequential damages could be very small. Indeed, even under the principle of Hadley v. Baxendale, once the seller has reason to know that a certain type of damages is probable, the buyer might not be required to communicate how high the damages could be. ${ }^{91}$ Furthermore, information that would put a reasonable person on notice might not give a particular seller actual knowledge. Therefore, the primciple does not protect a seller against consequential damages that the seller should have known, but did not in fact know, would probably occur. Accordingly, the principle of Hadley v. Baxendale serves the interests of sellers in an indirect, helter-skelter, and

90. See supra text accompanying notes 78-80.

91. See supra notes $70-73$ and accompanying text. 
often irrelevant manner. In contrast, contractual allocations of loss serve the ends of sellers directly-and perhaps more importantly, directly serve the varying ends of individual sellers. Accordingly, the enforcement of contractual allocations of loss, subject to a requirement of fair disclosure, is a central element of an appropriate liability-limitation regime.

\section{Fair Disclosure}

Contractual allocations of loss should be valid only if they comply with all the general standards of contract law. The most salient of these standards is that of fair disclosure. Because a contractual allocation of loss changes the normal expectation of compensation for loss, such an allocation should be enforceable only if it is brouglit home to the buyer so that the buyer will not be unfairly surprised.

The obhgation to bring home such a provision entails either pointing out the relevant provision to the buyer or else presenting the provision so that persons of the kind who enter into tlie relevant type of contract would not fail to see it. The obhigation to bring home also entails ensuring that the provision is written or explained so tliat the buyer understands both that on breach he will not receive full compensation and exactly how damages will be measured or limited.

The disclosure requirement should be especially demanding where the buyer is a consumer, because consumers ordmarily would have little or no understanding of tlie impact of certain kinds of contractual allocations-for example, provisions that deny consequential damages-unless the provision's effect is spelled out in ordinary, nontechnical language. For comparable reasons, a relatively strong requirement of disclosure should be imposed when the buyer is a sinall merchant. In general, the standard of disclosure sliould be based on wliat a reasonable person in the seller's position would believe is required to bring home the impact of the relevant contractual allocation to persons witl the sophistication normally found in the relevant buyers, unless the seller has reason to know that the actual buyer has greater sophistication. Assuming, however, that a contractual allocation is brought home and meets any other relevant legal standards, it should be fully enforced in accordance with its terms.

A buyer should also be under an obligation of fair disclosure, although of a different sort. If a buyer knows or has reason to know that the seller would be unlikely to enter into the contract if it understood its liability exposure, fairness requires the buyer to disclose, at the time a contract is made, information concerning the prospect of his damages on breach. This principle is especially relevant when the buyer knows or lias reason to know that its damages would be significant in proportion to the 
seller's net worth, that the seller would be unlikely to understand his liability risk unless disclosure is made, and that the seller is not sufficiently sophisticated to bargain for a contractual allocation of loss.

A requirement of fair disclosure by the buyer is justified under the existing doctrines of good faith or unconscionability, and under section 351(3) of the Restatement (Second) of Contracts, which provides that "[a] court may limit dainages for foreseeable loss by excluding recovery for loss of profits, by allowing recovery only for loss incurred in reliance, or otherwise if it concludes that in the circumstances justice so requires in order to avoid disproportionate compensation." 92

Fair disclosure can also be justified by a rerationalization of cases decided under the principle of Hadley v. Baxendale. For example, the result in Victoria Laundry, in which the buyer was not allowed to recover its expected very high dyeing profits, does not seem justified by the principle of Hadley v. Baxendale itself, but might be justified by the principle of fair disclosure. The seller had not manufactured the boiler that it sold, nor was it a dealer in boilers. ${ }^{93}$ The court characterized the seller as an "engineering firm," 94 and it seems likely that it was a relatively small and unsophisticated company. If those were the circumstances, Victoria might have been obliged to disclose to the seller its expected profits if they were likely to be significant in proportion to the seller's worth.

\section{B. The Comparative Advantages of the Alternative Regime}

The comparative advantage of a regime of proximate cause, contractual allocations of loss, and fair disclosure as an alternative to the Hadley regime can be demonstrated on a number of fronts:

First, the principle of Hadley v. Baxendale provides inefficient incentives for the rate of perfornance by allowing the seller, in deternnining whether to breach, to disregard reasonably foreseeable costs. In contrast, under a regime of proximate cause, contractual allocations of loss, and fair disclosure, the seller normally cannot disregard reasonably foreseeable costs except to the extent that the parties have specifically determined, as reflected in their agreement, that an allocation of costs to the buyer would make the contract more valuable than an allocation to the seller.

Second, the principle of Hadley v. Baxendale inefficiently dinninishes the incentives of buyers to invest in information when the value of the inforination to the buyer would be diminished if the infornation was transmitted. In contrast, under a regime of proximate cause, contractual

92. Restatement (SECOND) OF CONTRACTS § 351(3) (1979).

93. Victoria Laundry (Windsor) Ltd. v. Newman Indus. Ltd., [1949] 2 K.B. 528, 540 (Eng. C.A.).

94. Id. 
allocations of loss, and fair disclosure, a buyer normally does not have to convey any sensitive information, but at most simply accepts or rejects a substitute remedy or a dollar or formula limit on liability, elects a chosen combination of price and hability, or bargains for a higher level of liability.

Third, the primciple of Hadley v. Baxendale fails to promote effciency and defeats reasonable expectations when buyers do not know the intricacies of damage law. Correspondingly, because the principle of Hadley v. Baxendale conflicts with reasonable expectations, a buyer must know the intricacies of damage law to understand that he needs to contract around that principle. In contrast, when a contractual allocation of loss is employed, the buyer by hypothesis knows the rule that will govern his rights and obligations. Similarly, a seller need not know the law to understand that he needs to contract around the alternative regime; he need only know that he wants to limit his hability.

Fourth, the principle of Hadley v. Baxendale is often beside the point, even to sellers, because sellers are typically interested im protection agamst supranormal damages, whether direct or consequential and whether or not probable.95

Fifth, by its nature the principle of Hadley v. Baxendale is applied to many cases in which its rationale is inapplicable-for example, cases in which the seller is not interested in utilizing information on consequential dainages to stratify his level of precaution. Correspondingly, the primciple of Hadley v. Baxendale forces the buyer to incur costs for communcating information that the seller will not use. In contrast, a contractual allocation of loss will be employed only when it is in the actual interests of the parties and does not require the commumication of information that the seller will not use.

It might be argued that under a legal regime that makes promisors hable for reasonably foreseeable damages, sellers who now rely on the primciple of Hadley v. Baxendale would simply adopt contractual provisions replicating that principle. A well-informed seller, lowever, would not put much confidence im the principle of Hadley v. Baxendale because its operation is somewhat indeterminate. Furthermore, the real interest of sellers is in limiting supranormal damages, including not only direct damages but also tliose consequential dainages that can be recovered under the principle of Hadley v. Baxendale. The principle of Hadley v. Baxendale does not address that interest. In any event, even if sellers did adopt provisions replicating the principle of Hadley v. Baxendale, buyers would be no worse off than they are under the current regime, and indeed would be much better off. Many or most buyers are probably unaware of the principle of Hadley v. Baxendale, but all buyers would have to be

95. See supra text accompanying note 91 . 
made aware of equivalent contractual provisions that would not be effective unless brought home. In fact, one advantage of the regime of proximate cause, contractual allocations of loss, and fair disclosure is just the advantage claimed for Hadley v. Baxendale: it would force information about the damage rules that will govern a buyer's losses. Similarly, if the courts are rigorous in ensuring that contractual allocations of loss are brought home and in reviewing such provisions with special care when they are used in a monopotistic setting, the force of coinpetition should help to ensure that either varymg forms of contractual allocations of loss are offered by different sellers or that any allocation that emerges in equilibrium is one that maximizes the value of the relevant contracts.

In summary, even if the primciple of Hadley $v$. Baxendale produces benefits in excess of its costs as an abstract proposition, which is very unlikely, the primciple is nevertheless unjustified. The benefits it might conceivably achieve can be better achieved at far less cost by a regime of proximate cause, contractual allocations of loss, and fair disclosure.

\section{A Counter-Argument}

In an important article on default-rule inethodology, Ayres and Gertner argue that the primciple of Hadley v. Baxendale, which they forinnlate as a rule tliat precludes the recovery of unforeseeable damages, is preferable as a default rule to a non-Hadley regime, which they formulate as a rule that awards unforeseeable damages. ${ }^{96}$ The argument, which is pitched in terms of tle facts of Hadley v. Baxendale, is as follows:

Assume that Hadley is in place. Carriers who have contracted with millers conld avoid consequential damages to higlt-damage inillers at less cost than those millers. Failure to take extra precautions to avoid such damages would be inefficient, and high-damage millers would be willing to pay the carriers to take extra precautions. In tlie absence of contracting-around, carriers would not take the extra precautions because under Hadley they would not be hable for high dainages. There would then be an efficiency loss, equal to the unrealized benefit of reducing the probability of damages to high-damage inillers minus the increased cost that the increased precautions would entail. However, if the cost of contracting around Hadley is smaller than the loss from the inefficient level of precaution the carriers would otherwise take, higli-damage millers will contract around the default rule by identifymg themselves and bargaining for greater carrier hability at higher prices. Carriers will then take extra (efficient) precautions for the shipments of those millers.

96. Ayres \& Gertner, supra note 14, at 101-04, 108. 
Now assume that the regime of proximate cause is in place. ${ }^{97}$ If carriers cannot distimguish between high- and low-damage millers, they will charge an equilibrium price equal to the weighted average cost, including expected hability payments, of serving all millers. This equilibrium price will be a function of the percentage of high-damage millers. If that percentage is sufficiently low, the equilibrium price will be low, and the gain to low-damage millers from contracting-around may be less than the transaction costs of contracting-around. Low-damage millers then will not contract around the regime of proximate cause. Therefore, Ayres and Gertner argue, under Hadley there will be efficient contracting-around by high-damage millers, but under the regime of proximate cause there will not be efficient contracting-around by low-damage millers..$^{98}$

In analyzing this argument I will partly use Ayres and Gertner's shipper/miller terminology. Because the emphasis of their argument is on the efficient rate of precaution, it is important to bear im mind that their analysis does not depend sinply on the rate of contracting-around in the normal sense of that term, but on the rate of contracting-around that includes a stratification of precaution that would not otherwise occur.

A basic problem with the argument is that Ayres and Gertner imphicitly or exphicitly assume that the cost of contracting around Hadley is significantly less than the efficiency losses that will result if Hadley is not in force, and that the cost of contractimg around a regime of proximate cause is significantly more than the consequent reduction in price to those buyers who are willing to limit their damages. In fact, just the reverse is true.

To begiu with, the transaction costs of contracting around Hadley and stratifying precautions are very heavy. The cost of commumicating the relevant information is likely to be substantial-extreinely so in the case of information that loses value when transmitted. ${ }^{99}$ The cost of processimg the information is also likely to be very substantial. ${ }^{100}$ Most important, when the rate of breach is very low, as is usually the case, the cost of stratifying precaution is likely to be preclusive, which undoubtedly is why airlines, express-mail services, and household movers usually do not stratify precaution even when they know their hability exposure is supranormal. ${ }^{101}$ Because the costs of contracting around Hadley, includ-

97. Ayres and Gertner call this simply "non-Hadley," see id. at 110, but I will here call it "the regime of proximate cause," which involves a requirement of foreseeability.

98. See id. at 108-12.

99. See supra text accompanying note 81 .

100. See supra Section III.C.5.a.

101. See supra text accompanyiug notes 78-80. 
ing the costs of stratifying precaution, are so high, in practice contracting around Hadley is unlikely to occur at a significant rate.

In contrast, the costs of contracting around a regime of proximate cause are relatively sinall. Contracting around that regime requires neither inuch commumication or information processing, nor a stratification of precaution. Information about the buyer's probable consequential damages normally need not be either commumicated by the buyer or processed by the seller. Instead, sellers who wish to use contractual allocations of loss need only incur the one-time cost of determining what allocation they prefer, and buyers need only determine whether a given seller's contractual provisions are acceptable or what combination of price and hability the buyer prefers. Although in some cases buyers and sellers will negotiate over the allocation of losses, if the relevant market is reasonably competitive, and sellers are required to bring home contractual allocations of loss, the force of competition ordinarily should lead to provisions that are satisfactory to most buyers without negotiation. ${ }^{102}$

Ayres and Gertner argue that "in many situations ... [d] [devising a menu that induces information revelation may require a great deal of sophistication by the [party that wants the inforination] and may entail large transaction costs." 103 To support this argument, Ayres and Gertner rely principally on the resistance that consumers encounter in getting information from a dealer about the dealer's profits. ${ }^{104}$ The analogy is not apt. On the one hand, consumers are normally much less sophisticated than commercial sellers, and the cost to dealers of disclosing information concerning profits would usually be preclusive because of its effect on bargaining and its value to competitors. On the other, the cost to buyers of disclosing the amount of damages on breach is very low, at least in a reasonably competitive market in which such infornation would have hittle value to sellers.

Correspondingly, in practice shippers ordinarily would not use contractual provisions to induce the revelation of complex information, as Ayres and Gertner suggest, but only to allocate liability. Many sellers would employ a simple himitation on hability rather than a menu of choices. Most sellers could easily determine satisfactory ways to draft contractual allocations of loss. Those that could not would retain experts. Even if the one-time cost of drafting a contractual allocation of loss was high, it would be spread over so many transactions that the

102. If the relevant market is not reasonably competitive, such provisions might require special scrutiny. See Henningsen v. Bloomfield Motors, Inc., 161 A.2d 69 (N.J. 1960) (refusing to enforce a car manufacturer's disclaimer of the implied warranty of merchantability in a personal-injury context where the manufacturers that accounted for most production had adopted a uniform disclaimer)."

103. Ayres \& Gertner, supra note 14, at 103.

104. Id. at $103 \&$ n.71, $105 \&$ n.81. 
drafting cost per transaction would be close to zero. Furthermore, the issue under a regime of proximate cause is not, as Ayres and Gertner put it, whether low-damage buyers would have a sufficient incentive to come forward and reveal their status so as to receive a lower contract price. Rather, sellers who wanted to stratify their prices or their levels of precaution would utilize contract provisions that required buyers to elect a liability level, and buyers would be required merely to make that decision. ${ }^{105}$ High-volume sellers can very cheaply elicit information about whetler buyers prefer low or high damages through the proffer of priceliability choices or other contractual allocations. The incentive for the seller to elicit such information is maximized under a regime of proximate cause and minimized under Hadley.

Finally, Ayres and Gertner do not confront the relative costs that Hadley and a regime of proximate cause impose. Here too the costs of Hadley are very high, while the costs of a regime of proximate cause are very low. Hadley provides inefficient incentives for the rate of performance and the rate of investment in information. A regime of proximate cause does not. Hadley defeats reasonable expectations. A regime of proximate cause does not. ${ }^{106}$

105. Cf. Jeffrey M. Perloff, Breach of Contract and the Foreseeability Doctrine of Hadley v. Baxendale, 10 J. LEGAL STUD. 39, 50-51 (1981) (discussing buyers' varying incentives to reveal potential damages).

106. In Lucien Bebchuck \& Steven Shavell, Information and the Scope of Liability for Breach of Contract: The Rule of Hadley v. Baxendale, 7 J.L. ECON, \& ORGANIZATION 286 (1991), the authors make an argument that is highly comparable to that of Ayres and Gertner and is generally subject to the same objections. In particular, the analysis gives undue weight to precautions that in reality will not be taken, and largely considers only the cost of transmitting information on a transaction-bytransaction basis. One difference between the two analyses is that Bebchuck and Shavell's analysis is somewhat more generalized. A positive aspect of this greater level of generalization is that some of Bebehuck and Shavell's propositions based on the relative costs of commumication and noncommunication are phrased broadly enough to be unobjectionable if costs are understood to include all the costs of a given regime-including, for example, the costs of creating and maintaining internal systems to identify, generate, and process the relevant information (much or most of which will not be used); the cost of transmitting information that loses its value to the buyer when transmitted; the cost of defeated expectations; and the cost of inefficient breach. A negative aspect of the greater generalization is that some of the legal and factual premises of Bebchuck and Shavell's models do not correspond to real law and real facts. For example, the models assume that the alternative to Hadley v. Baxendale is "untimited hability for breach," $i d$ at 285 , that sellers who are "informed of a buyer's high valuation ... will take proper measures to increase the hikelihood of performance," id. at 286, and that if Hadley v. Baxendale were not the law, "high valuation buyers will never communicate," id. at 296. In fact, however, the real alternative to Hadley v. Baxendale is reasonable foresecability, not unlimited liability; sellers will frequently if not typically fail to take extra precautions even when they are dealing with known high-valuation buyers; and high-valuation buyers can be made to communicate, whether or not Hadley v. Baxendale is the law, by the use of contractual hinitations of hability, and would communicate even in the absence of such provisions when their losses were not reasonably foreseeable. (Bebchuck and Shavell do take limited account of some of these real-world facts in a section on extensions of the models, see id. at 406-07, but they do not draw out the full implications of these facts for the models themselves.) 
$\mathrm{V}$

\section{The EMERGENCE OF THE NEW Regime}

The substitution of a regime of proximate cause, contractual allocations of loss, and fair disclosure for the regime of Hadley v. Baxendale would not mark a radical break with existing law. Rather, it would instead complete a inetamorphosis that modern business practice and modern contract law have already been undergoing.

\section{A. Modern Business Practice}

In terms of modern business practice, sellers today commonly employ contractual provisions that either preclude consequential damages, put a dollar or formula limit on hability, offer varying liability limits in exchange for varying prices, or substitute for dollar liability some other obligation, such as replacement or repair. Indeed, in tlie case of the sale of goods, such provisions are virtually invited by section 2-719 of the Uniform Commercial Code (UCC). Under section 2-719(1)(a), an agreement for the sale of goods "may provide for remedies in addition to or in substitution for those provided in [the UCC] and may limit or alter tlie measure of damages recoverable under [tle UCC], as by limiting the buyer's remedies to return of the goods and repayment of the price or to repair and replacement of non-conforming goods or parts." 107 Under section 2-719(3), "[c]onsequential damages may be limited or excluded unless the limitation or exclusion is unconscionable." 108

A menu of varying hability limits coupled with varymg prices is frequently achieved by offermg buyers a clioice between a basic price witl limited dollar liability, or mcreased hability im exchange for add-ons to the basic price. Altliough these add-ons are sometimes denominated as "insurance," in substance they amount to a stratification of price because third-party insurers are usually not imvolved. Significantly, sellers who use such provisions, and therefore lave actual knowledge about which buyers will have high damages on breach, appear to devote no special precaution to the contracts of those buyers, presumably because of the cost of stratification. The wide use of allocation provisions in modern busmess practice gives evidence botll that the principle of Hadley $v$. Baxendale does not meet sellers' real needs, and that a regime of proximate cause, contractual allocations of loss, and fair disclosure would work little more tlian a ripple in modern practice.

107. U.C.C. $\$ 2-719(1)(a)(1990)$.

108. Id. \& 2-719(3). 


\section{B. Modern Contract Law}

In teruns of modern contract law, the history of the principle of Hadley v. Baxendale over the last fifty or sixty years has been one of steady relaxation of the standard of foreseeability. At the height of classical contract law, the principle was sometimes mterpreted to exclude consequential damages unless the seller had made a "tacit agreement" to pay such damages. ${ }^{109}$ This view has long since been generally abandoned. ${ }^{110}$

Similarly, the traditional formulation and application of Hadley $v$. Baxendale, which precludes the recovery of damages uuless the seller has reason to know that the damages will be the probable or even highly probable result of breach, has steadily been eroding. The case law up through the 1950 s is well summarized by Lord Reid in The Heron II: "For a considerable time there was a tendency to set narrow limits to awards of damages."111

In that case, however, the House of Lords adopted formulations that are significantly easier to satisfy. Recall that the vessel in that case had made deviations im breach of contract, and as a result the shipper's cargo of sugar arrived in Basrah late, by which time sugar prices had dropped. The carrier had reason to know that sugar prices in Basrah would fluctuate, but it "had no reason to suppose it more probable that during the relevant period such fluctuation would be downward rather than upwards-it was an even chance that the fluctuation would be downwards." 112 The House of Lords nevertheless held the carrier liable for the difference between the market prices on November 22 and December 2. Although the various opimions differed somewhat as to the precise refornulation of the test, most of the opimions approved the terins "liable to result," "real danger," or "serious possibility." These reformulated tests all allow the recovery of consequential damages even though a reasonable person would not have thought that the damages were "probable" when the contract was made. The "serious possibility" test, im particular, can easily be transmuted into a test of reasonable foreseeability-that is, a test that centers on whether the prospect that damage will result is more than marginal, or not imsignificant.

Two of the three judges in $H$. Parsons (Livestock) Ltd. v. Uttley Ingham \& Co. went notably further. ${ }^{113}$ In that case Lord Scarman con-

109. See supra note 24 and accompanying text.

110. See, e.g., U.C.C. $\S 2-715 \mathrm{cmt} .2$ (1990); ResTatement (SECOND) OF ConTRACTS $\S 351$ cmt. a (1979); 3 FARNSwORTH, supra note $18, \S 12.14$, at 243-44 nn. 9-11. But see Morrow v. First Nat'l Bank, 550 S.W.2d 429, 430-31 (Ark. 1977).

111. Koufos v. C. Czarnikow Ltd. [The Heron II], [1969] 1 App. Cas. 350, 387 (1967) (appeal taken from Eng.) (opinion of Lord Reid).

112. Id. at 382 .

113. [1978] 1 Q.B. 791 (Eng. C.A. 1977). 
cluded that contract and tort were to be reconciled by ratcheting down the formulation of Hadley v. Baxendale so that it equates with the principle of proximate cause-thereby standing on its head the opinion in The Wagon Mound I, which had abortively tried to ratchet up proximate cause so that it equated with the traditional formulation of Hadley $v$. Baxendale. Lord Scarman said:

[T] he law is not so absurd as to differentiate between contract and tort save in situations where the agreenent, or the factual relationship, of the parties with each other requires it in the interests of justice. ...

...

... [T] The law inust be such that, in a factual situation where all have the saine actual or imputed knowledge and the contract contains no term limiting the damages recoverable for breach, the amount of damages recoverable does not depend upon whether, as a inatter of legal classification, the plaimtiff's cause of action is breach of contract or tort. It may be that the necessary reconciliation is to be found, notwithstanding the strictures of Lord Reid [in The Heron II], in holding that the difference between 'reasonably foreseeable' (the test in tort) and 'reasonably contemplated' (the test im contract) is semantic, not substantial.

$\cdots \cdots$

... Though in loss of inarket or loss of profit cases the factual analysis will be very different from cases of physical injury, the same principles, in my judgment, apply. Given the situation of the parties at the time of contract, was the loss of profit, or narket, a serious possibility, something that would have been in their minds had they contenplated breach? ${ }^{114}$

Lord Scarman's opinion (concurred in by Lord Justice Orr), ${ }^{115}$ which brimgs the principle of Hadley v. Baxendale into equilibriun with a reasonable-foreseeability conception of proxinate cause, subject to the right of the parties to agree on a different allocation of damages and "save in situations where the agreement, or the factual relationship, of the parties which each other requires [a different result] in the interests of justice," 116 is almost precisely equivalent to the regime that $I$ have suggested here.

In the Umited States as well, the trend of the cases has been to relax the standard of foreseeability required under the principle of Hadley $v$. Baxendale. ${ }^{117}$ This trend, in turn, can be seen as part of a wider recogni-

114. Id. at $806,807,813$ (opinion of Scarman, L.J.).

115. Id. at 804-05 (opinion of Orr, L.J.).

116. Id. at 806 (opinion of Scarman, L.J.).

117. See, e.g., Hector Martinez \& Co. v. Southern Pac. Transp. Co., 606 F.2d 106 (5th Cir. 1979); Wullschleger \& Co. v. Jenny Fashions, Inc., 618 F. Supp. 373 (S.D.N.Y. 1985); Prutch v. Ford Motor Co., 618 P.2d 657 (Colo. 1980); Miles v. Kavanaugh, 350 So. 2d 1090 (Fla. Dist. Ct. App. 1977); Midland Hotel Corp. v. Reuben H. Donnelley Corp., 515 N.E.2d 61 (Ill. 1987); R.I. Lampus Co. v. Neville Cement Prods. Corp., 378 A.2d 288 (Pa. 1977); see also DoBBS, supra note $16, \S 12.3$, at 813 . 
tion that contract damages tend to be undercompensatory, and that undercompensation is at least as inefficient as overcompensation. ${ }^{118}$

Another inportant American developinent that may ultimately point in the same direction is to be found in Restatement (Second) of Contracts section 351. Section 351(1) is a clear statement of the classical formulation of the primciple: "Damages are not recoverable for loss that the party in breach did not have reason to foresee as a probable result of the breach when the contract was made."119 Section 351(3), however, provides: "A court may limit damages for foreseeable loss by excluding recovery for loss of profits, by allowing recovery only for loss incurred in reliance, or otherwise if it concludes that in the circumstances justice so requires in order to avoid disproportionate compensation." 120

Because Restatement (Second) of Contracts section 351(1) states the principle of Hadley v. Baxendale in traditional ternns, it might seen that section 351(3) only adds a new and additional limit on damages. In substance, however, section 351(3) radically undermines the principle of Hadley v. Baxendale. Properly understood, the concept that damages may be limited in cases where justice so requires does not add to, but instead swallows up, the principle of Hadley v. Baxendale. ${ }^{121}$ For the reasons developed in this Article, justice is best served by a regime based on proximate cause, contractual allocations of loss, and fair disclosure.

118. See Michael Traynor, Bad Faith Breach of a Commercial Contract: A Comment on the Seaman's Case, 8 BuS. L. NEws 1, 12-13 (1984); cf. Daniel A. Farber, Reassessing the Economic Efficiency of Compensatory Damages for Breach of Contract, 66 VA. L. REV. 1443 (1980) (criticizing the underenforcement of contracts).

119. Restatement (SECOND) OF CONTRACTS $\S 351(1)$ (1979).

120. Id. §351(3).

121. Indeed, there is some ambiguity about $\S 351(1)$ itself. Section $351(2)$ provides: "Loss may be foreseeable as a probable result of a breach because it follows from the breach (a) in the ordinary course of events, or (b) as a result of special circumstances, beyond the ordinary course of events, that the party in breach had reason to know." Id. § 351(2).

The introductory clause of $\S 351(2)$ states that the crucial test of $\S 351(1)$-whether the party in breach had "reason to foresee [that the damages in question would be] a probable result of the breach"-is satisfied if either $\S 351$ (2)(a) or (b) is satisfied. Section 351(2)(b), however, can easily be read as a rule of reasonable foreseeability. Accordingly, $\S 351$ can be interpreted to mcan that satisfaction of a test of reasonable foreseeability under $\S 351(2)(b)$ is sufficient to satisfy the "probable result of a breach" test under $\S 351(1)$.

The comment to $\S 351(1)$ is split the same way as the text. The first sentence of comment a states: "A contracting party is generally expected to take account of those risks that are foreseeable at the time he makes the contract." $I d$. at $\S 351 \mathrm{cmt}$. a (emphasis added). The next few sentences, on the other hand, state:

[A contracting party] is not, however, hable in thc event of breach for loss that he did not at the time of contracting have reason to foresee as a probable result of such a breach. The mere circumstance that some loss was foreseeable, or even that some loss of the same general kind was foreseeable, will not suffice if the loss that actually occurred was not foreseeable. It is enough, however, that the loss was foreseeable as a probable, as distinguished froin a necessary, result of his breach.

Id. (emphasis added). 


\section{CONCLUSION}

The empliasis of classical contract law on certainty, liability-limiting devices, and standardized rules led to the embrace of a variety of artificial limits on expectation damages in general, and lost profits in particular. One of the most important of these limits was the principle of Hadley v. Baxendale. The continued survival of that principle might liave been due in part to its ability to serve as a rougli surrogate for a principle of fair disclosure. The problem of fair disclosure is most salient in dealings that involve small firms; the principle of Hadley v. Baxendale imiglit liave served an important function in an era in which small firns were very important and in which the courts often thouglit that fairness issues could not be directly addressed in contract law. The survival of the principle miglit also liave been due in part to an incorrect perception that the principle of Hadley v. Baxendale inerely requires foreseeability and that dropping the principle would therefore entail dropping foreseeability as a limitation on contract damages. ${ }^{122}$

As business conditions liave clianged, as profits lave come to be recognized as central to business value, and as econormic analysis has slown that expectation damages are both fair and efficient, ${ }^{123}$ the artificial limits classical contract law placed on expectation damages and lost profits have gradually been falling away, and contract law has been moving toward the goal of full coinpensation. So, for example, the certainty rule lias been substantially restricted botll in common law decisions ${ }^{124}$ and under the Uniform Commercial Code; ${ }^{125}$ the new-business rule has been all but abohished; ${ }^{126}$ and the rule thiat precluded a seller of goods from recovering lost profits lias been replaced by a rule that allows the seller to recover both lost profits and overliead. ${ }^{127}$

The conditions that liave led to those changes liave also led to a significant relaxation of the standard of foreseeability under the principle of Hadley v. Baxendale. This relaxation has undoubtedly been due as well to an economic shift froin small firms to higl1-volume sellers who lave the capacity to deal witl liability by the use of probabilistic techinques, and to the everyday use of contractual allocations of loss to limit

122. See, e.g., Ayres \& Gertner, supra note 14, at 101 (reading Hadley v, Baxendale to stand for the principle that "only foreseeable consequential damages should be awarded").

123. See supra text accompanying notes $35-38$.

124. See, e.g., Lexington Prods. Ltd. v. B.D. Commumications, Inc., 677 F.2d 251 (2d Cir. 1982) (allowing proof of contract damages based on statistics and probabilities); Contemporary Mission, Inc. v. Famous Music Corp., 557 F.2d 918, 926 (2d Cir. 1977) (same); Rombola v. Cosindas, 220 N.E.2d 919 (Mass. 1966) (same).

125. See U.C.C. $\S 1-106 \&$ cmt. 1 (1990).

126. See, e.g., Fera v. Village Plaza, Inc., 242 N.W.2d 372 (Mich. 1976) (upholding an award of $\$ 200,000$ for "anticipated lost profits" resulting from a breach of a lease for a new business).

127. See U.C.C. $\$ 2-708$ (1990); see also Neri v. Retail Marine Corp., 285 N.E.2d 311 (N.Y. 1972). 
liability. Perhaps too there has been an increase in sophistication and in the awareness and assessinent of probabilities, so that risks that would at one time have been considered to be remote are now considered to be at least likely.

As a result of these developinents, contract law is now ready to substitute for the regime of Hadley $v$. Baxendale a regime in which hability, to the extent not controlled by contractual allocations of loss and the principle of fair disclosure, would fall within the general principle of proximate cause. Under this regime, the standard of foreseeability required should vary according to the nature of the interest invaded and the wrong involved; when lost profits or forgone opportunities are involved, the baseline standard of reasonable foreseeability should be apphed; and the relevant standard should be apphied at the time of the breach. If adoption of a proximate-cause regime seeins too radical to the courts, they should at least follow the trend of the case law and the teaching of $H$. Parsons (Livestock) Ltd. v. Uttley Ingham \& Co. and reinterpret the principle of Hadley v. Baxendale so that it requires only that a loss be reasonably foreseeable, not that it be the probable resnlt of the breach. ${ }^{128}$

128. This alternative approach might be required in cases decided under the UCC. Sections 2714 and 2-715 of the UCC distinguish between (1) damages for injury to person or property caused by breach of warranty, which are governed by the standard of proximate cause, and (2) other consequential damages, which are defined to include "any loss resulting from general or particular requirements and needs of which the seller at the time of contracting had rcason to know," U.C.C. $\$ 2-715$ (2)(a) (1990). Because of this explicit distinction, applying the standard of proximate cause, as such, might not be proper in assessing consequential damages under the UCC im cases that do not fall within $\$ 2-714(1)$.

On the other hand, the "reason to know" standard of $\S 2-715(2)$ of the UCC lends itself naturally to the reasonably foreseeable interpretation suggested in this Article. See Prutch v. Ford Motor Co., 618 P.2d 657, 662 (Colo. 1980) ("The statutory 'reason to know' standard [of the UCC], in our view, triggers liability for consequences that may not have been actually foreseen but which were foreseeable."). 
